\title{
CRISPR/Cas9-mediated heterozygous knockout of the autism gene CHD8 and characterization of its transcriptional networks in cerebral organoids derived from iPS cells
}

Ping Wang ${ }^{1 \dagger}$, Ryan Mokhtari ${ }^{2 \dagger}$, Erika Pedrosa ${ }^{2}$, Michael Kirschenbaum ${ }^{2}$, Can Bayrak ${ }^{3}$, Deyou Zheng ${ }^{1,4,5^{*}}$ and Herbert M. Lachman ${ }^{1,2,5,6^{*}}$

\begin{abstract}
Background: CHD8 (chromodomain helicase DNA-binding protein 8), which codes for a member of the CHD family of ATP-dependent chromatin-remodeling factors, is one of the most commonly mutated genes in autism spectrum disorders (ASD) identified in exome-sequencing studies. Loss of function mutations in the gene have also been found in schizophrenia (SZ) and intellectual disabilities and influence cancer cell proliferation. We previously reported an RNA-seq analysis carried out on neural progenitor cells (NPCS) and monolayer neurons derived from induced pluripotent stem (iPS) cells that were heterozygous for CHD8 knockout (KO) alleles generated using CRISPRCas9 gene editing. A significant number of ASD and SZ candidate genes were among those that were differentially expressed in a comparison of heterozygous $\mathrm{KO}$ lines $\left(\mathrm{CHD}^{+/-}\right)$vs isogenic controls $\left(\mathrm{CHD}^{+/-}\right)$, including the $\mathrm{SZ}$ and bipolar disorder (BD) candidate gene TCF4, which was markedly upregulated in $\mathrm{CHD8}^{+/-}$neuronal cells.
\end{abstract}

Methods: In the current study, RNA-seq was carried out on $\mathrm{CHD}^{+/-}$and isogenic control $\left(\mathrm{CHD}^{+/+}\right)$cerebral organoids, which are 3-dimensional structures derived from iPS cells that model the developing human telencephalon.

Results: TCF4 expression was, again, significantly upregulated. Pathway analysis carried out on differentially expressed genes (DEGs) revealed an enrichment of genes involved in neurogenesis, neuronal differentiation, forebrain development, Wnt/ $\beta$-catenin signaling, and axonal guidance, similar to our previous study on NPCs and monolayer neurons. There was also significant overlap in our $\mathrm{CHD}^{+/-}$DEGs with those found in a transcriptome analysis carried out by another group using cerebral organoids derived from a family with idiopathic ASD. Remarkably, the top DEG in our respective studies was the non-coding RNA DLX6-AS1, which was markedly upregulated in both studies; DLX6-AS1 regulates the expression of members of the $D L X$ (distal-less homeobox) gene family. $D L X 1$ was also upregulated in both studies. DLX genes code for transcription factors that play a key role in GABAergic interneuron differentiation. Significant overlap was also found in a transcriptome study carried out by another group using iPS cell-derived neurons from patients with BD, a condition characterized by dysregulated WNT/ $\beta$-catenin signaling in a subgroup of affected individuals.

(Continued on next page)

\footnotetext{
* Correspondence: Deyou.Zheng@einstein.yu.edu;

Herb.Lachman@einstein.yu.edu

${ }^{\dagger}$ Equal contributors

'Department of Genetics, Albert Einstein College of Medicine, 1300 Morris

Park Ave, Bronx, NY, USA

Full list of author information is available at the end of the article
} International License (http://creativecommons.org/licenses/by/4.0/), which permits unrestricted use, distribution, and reproduction in any medium, provided you give appropriate credit to the original author(s) and the source, provide a link to the Creative Commons license, and indicate if changes were made. The Creative Commons Public Domain Dedication waiver (http://creativecommons.org/publicdomain/zero/1.0/) applies to the data made available in this article, unless otherwise stated. 
(Continued from previous page)

Conclusions: Overall, the findings show that distinct ASD, SZ, and BD candidate genes converge on common molecular targets - an important consideration for developing novel therapeutics in genetically heterogeneous complex traits.

Keywords: DLX6-AS1, Distal-less homeobox, Gabaergic, Cancer, Autism, Schizophrenia, Bipolar disorder, TCF4, HMGA2, ZNF132, Wnt, Beta-catenin

\section{Background}

Chromodomain helicase DNA-binding protein 8 (CHD8) has emerged as a top ASD candidate gene from multiple exome-sequencing studies [1-4]. Loss of function mutations in the gene have also been found in schizophrenia (SZ) and intellectual disabilities [4-6]. CHD8 is a ubiquitously expressed member of the CHD family of ATPdependent chromatin-remodeling factors that play important roles in chromatin dynamics, transcription, and cell survival [7-11]. Previous studies have shown that CHD8 protein negatively regulates Wnt signaling by interacting with $\beta$-catenin: Wnt $/ \beta$-catenin signaling plays a critical role in normal brain development and has been implicated in bipolar disorder (BD), SZ, ASD, and cancer $[4,10,12-23]$. The effect of CHD8 on the growth of cancer cells appears to be due, in part, to an interaction with p53 [24]. CHD8 also recruits MLL histone methyltransferase complexes to regulate cell cycle genes [25] and binds to the chromatin insulator CTCF $[25,26]$. Recent work also shows that CHD8 and other CHD chromatin remodelers regulate embryonic stem cell transcriptional programs by targeting specific nucleosomes that flank nucleosome-free promoter regions [9].

Based on these observations, we have been studying the effects of CHD8 on human neurons and neural progenitor cells (NPCs) using $\mathrm{CHDS}^{+/-}$lines generated in isogenicinduced pluripotent stem (iPS) cells by CRISPR-Cas9 gene editing [8]. Other investigators have been studying the effect of CHD8 on neuronal cells using RNA interference (RNAi) [27-29]. These studies have focused primarily on analyzing downstream targets of CHD8 in order to identify differentially expressed genes (DEGs). This is a particularly useful strategy for studying ASD and SZ candidate genes that function as regulators of gene expression, in order to find converging pathways that could connect many different genetic risk factors into more manageable common molecular subgroups-an idea that could facilitate drug discovery. ASD and SZ candidate genes that code for gene expression regulators (e.g., transcription factors and chromatin-remodeling complexes) represent, along with genes that code for synaptic proteins, calcium channels, potassium channels, and the HLA (MHC) locus, the major categories of validated candidate genes in these conditions [4, 30-33]. Molecular genetic convergence has previously been demonstrated for some candidate genes. For example, the SZ and BD candidate gene MIR137 has been found to target other candidates: CSMD1, C10orf26, CACNA1C, and TCF4 [34]. In addition, clinically distinct disorders can be caused by the same risk genes, suggesting that therapies aimed at specific molecular targets could have a therapeutic effect across diagnostic categories [4, 35].

The molecular studies that have targeted CHD8 certainly support the concept of converging molecular targets and pathways. In shRNA knockdown studies and chromatin immunoprecipitation using NPCs, neural stem cells (NSCs), and SK-N-SH neuroblastoma cells, downregulation of CHD8 predicted a disruption of gene networks involved in neurodevelopment and resulted in altered expression of a significant number of other ASDrisk genes [3, 27-29].

Similarly, in our recently published study, a significant number of previously characterized ASD and SZ candidate genes were found to be differentially expressed in $\mathrm{CHDS}^{+/-} \mathrm{NPCs}$ and neurons, compared with isogenic controls [8], and furthermore, DEGs were found to overlap with the downstream targets of several other SZ and ASD candidate genes that code for transcription factors or chromatin regulators, including TCF4, EHMT1, and SATB2 [6, 8, 36-38]. This suggests that CHD8 not only has a direct effect on gene expression but has indirect effects as well. We also found that DEGs were enriched for pathways that affect the extracellular matrix (ECM), cell adhesion, neuron differentiation, neuron projection, synaptic transmission, axonal guidance signaling, and $\mathrm{WNT} / \beta$-catenin and PTEN signaling. In addition, genes involved in head circumference were found to be differentially expressed. This is notable because loss of function CHD8 mutations are associated with large head circumference, a finding that has been experimentally validated in a zebrafish model $[2,3]$.

Our previous study was carried out using NPCs and a monolayer neuronal culture system consisting of a fairly heterogeneous array of neurons expressing forebrain, midbrain, and hindbrain markers. Recently, several neuronal differentiation methods have emerged that are more suitable for SZ and ASD, one of which is the direct conversion of iPS cells into 3-dimensional cerebral organoids, which resemble a first trimester developing telencephalon [39-41]. This is particularly appropriate for studying neurodevelopmental disorders that are associated with cognitive dysfunction. We have also 
demonstrated that the organoid system is ideal for studying gene $x$ environment interactions relevant to neuropsychiatric and neurodevelopmental disorders [39].

The few studies that have been carried out so far using cerebral organoids as a model system have been revealing. Mariani et al., for example, showed that genes involved in cell proliferation, neuronal differentiation, synaptic assembly, and GABAergic inhibitory neuron development were differentially expressed in an idiopathic ASD family [42]. And, using a somewhat different organoid differentiation protocol, Lancaster et al. showed that cerebral organoids derived from patients with CDK5RAP2 loss of function variants and microcephaly have premature neuronal differentiation [41].

Accordingly, we have expanded our transcriptome analysis of CHD8 target genes in cerebral organoids derived from $\mathrm{CHDS}^{+/-}$iPS cells and isogenic controls. The DEGs reported here validate many of the findings in our previous analysis in NPCs and monolayer neuronal cultures. In particular, we show that CHD 8 haploinsufficiency again leads to a substantial increase in TCF4 expression [8]. In addition, significant overlap was found with the DEGs previously identified in the Mariani et al. study, which was carried out using subjects with idiopathic ASD in whom the responsible genetic variant could not be unequivocally characterized [42]. The long non-coding antisense RNA DLX6-AS1, a regulator of GABAergic interneuron development [43], was the top DEG in both. Considering the genetic heterogeneity found in ASD and SZ, the molecular convergence on DLX6-AS1 between CHD8 and an uncharacterized ASDcausing genetic variant is striking.

\section{Methods}

\section{Development of iPSCs from skin fibroblasts}

We have been developing iPS cells from controls and patients with 22q11.2 del diagnosed with SZ or schizoaffective disorder [44]. One of the male control samples was used to generate the $\mathrm{CHD}^{+/-}$lines. The control was recruited from the Albert Einstein College of Medicine (AECOM). The study and consent forms were approved by the AECOM Institutional Review Board (IRB). Consent was obtained by a skilled member of the research team who had received prior human subjects training. iPSC lines were generated from fibroblasts obtained from skin biopsies performed by board-certified physicians. The procedure for growing fibroblasts in preparation for reprogramming into iPS cells is detailed in Additional file 1: Supplemental methods.

\section{Generating CHD8 KO lines}

$\mathrm{CHDS}^{+/-}$lines were developed by introducing a CRISPR-Cas9 vector containing $C H D 8$ guide sequences into iPS cells by nucleofection [8]. The procedure is described in detail in Additional file 1: Supplemental methods.

\section{Cerebral organoid differentiation}

The protocol is adapted from Mariani et al. [40]. Briefly, iPS cell colonies were maintained on matrigel in mTesr1. To induce cerebral organoid differentiation, iPS cells were pretreated with $50 \mu \mathrm{M}$ Y27632 in mTesr1 for $1 \mathrm{~h}$ at $37{ }^{\circ} \mathrm{C}$. Wells were rinsed with DMEM/F12, and iPS cell colonies were dissociated with accutase for $10 \mathrm{~min}$ at $37^{\circ} \mathrm{C}$. Cells were rinsed with DMEM/F12 and collected and counted for aggregate formation. Following the Stem Cell Technologies protocol, $3.0 \times 10^{6}$ cells were used to create 10,000 cell aggregates using an AggreWell $^{\mathrm{TM}}$ plate. For the first 6 days, aggregates were cultured in mTesr1 supplemented with $500 \mathrm{ng} / \mathrm{ml} \mathrm{DKK}$ 1, $1.5 \mu \mathrm{g} / \mathrm{ml}$ BMPRIA-Fc, and $10 \mu \mathrm{M}$ SB431542. On day 6, aggregates were removed from the AggreWell ${ }^{\mathrm{TM}}$ plate, according to the Stem Cell Technology protocol, and transferred to a 24-well ultra-low attachment plate. On day $18,1 \% \mathrm{~N} 2$ supplement was added to the medium. On day 25, aggregates were plated onto a 4-well chamber slide coated with $10 \mu \mathrm{g} / \mathrm{ml}$ polyornithine, $2.5 \mu \mathrm{g} / \mathrm{ml}$ laminin, and $50 \mu \mathrm{g} / \mathrm{ml}$ fibronectin, and cultured in Neurobasal medium supplemented with $2 \%$ B27 and $2 \mathrm{mM}$ L-glutamine until day 50. Organoids were detached, and RNA was extracted. Organoids are composed of a mixture of GABAergic and glutamatergic neurons, and radial glia progenitor cells, and have gene expression profiles that resemble a first trimester telencephalon (Additional file 2: Figure S1) [39, 40, 45]. For immunohistochemistry (IHC), samples were fixed with $4 \%$ paraformaldehyde and $25 \%$ sucrose, and then embedded in O.C.T (optimal cutting temperature) (see Additional file 1: Supplemental methods for IHS methodology).

\section{RNA-seq}

Total RNA was isolated using the miRNeasy kit (Qiagen) according to the manufacturer's instructions. We obtained 101 bp paired-end RNA-seq reads from an Illumina HiSeq 2500 instrument. Adapters and low quality bases in reads were trimmed by trim_galore (http://www.bioinformatics.babraham.ac.uk/projects/trim_galore/). We employed Kallisto (v0.42.5) [46] to determine the read count for each transcript and quantified transcript abundance as transcripts per kilobase per million reads mapped (TPM), using gene annotation in the GENCODE database (v18) [47]. Then we summed the read counts and TPM of all alternative splicing transcripts of a gene to obtain gene expression levels. We restricted our analysis to 12,898 expressed genes with an average TPM $>1$ in either wild type or $\mathrm{CHD}^{+/-}$samples. DESeq2 [48] was used to identify DEGs (false discovery rate (FDR) <0.05). The software DAVID (v6.8 Beta) $[49,50]$ was used for Gene Ontology 
(GO) analysis, with the 12,898 expressed genes as background. Ingenuity pathway analysis (IPA) (https:// www.qiagenbioinformatics.com/) was used for canonical pathway analysis, using the ingenuity knowledge base (genes only) as background. The RNA-seq data have been deposited in Gene Expression Omnibus (GEO: accession number GSE85417).

\section{Quantitative real-time PCR (qPCR)}

qPCR was carried out on reverse transcribed PCR using the $2^{-\Delta \Delta \mathrm{Ct}}$ method as previously described $[51,52]$. A detailed description and the primers used for this analysis can be found Additional file 1: Supplemental methods.

\section{ASD/SZ-risk gene sets}

For ASD, we compared our DEG list with the following ASD gene sets: SFARI [https://gene.sfari.org/autdb/ GS_Home.do] (genes scored as high confidence, to minimal evidence and syndromic); AutismKB (core dataset) [53]; a set of high-confidence ASD genes (Willsey_ASD) [54]; genes predicted by whole exome sequencing and co-expression network analysis (Liu_ASD) [55]; candidate genes with de novo mutations from massive whole exome sequencing (Iossifov_ASD) [56]; and candidates from the same dataset focusing on a combination of de novo and inherited mutations resulting in a highconfidence list $(F D R<0.1)$ (DeRubeis_ASD) [57]. The two SZ gene lists were from the SZ gene database [58] and a recent genome-wide association study (GWAS) report (SZC GWAS) [33]. These gene lists can be obtained from our previous publication [8].

\section{Comparison of $\mathrm{CHDB}^{+/-}$DEGs with idiopathic ASD organoids} The DEG list from $\mathrm{CHD}^{+/-}$organoids was compared to the DEG lists generated from idiopathic autism patientspecific organoids described by Mariani et al. [42]. The latter were obtained from two developmental stages, after 11 and 31 days of terminal differentiation (TD11 and TD31).

\section{Comparison of $\mathrm{CHD}^{+/-}$DEGs with BD patient-derived neurons}

DEG lists from Mertens et al. [59] were derived from the file "GSE58933_Jun_All_Data.txt.gz" in the GEO "GSE58933" record. For a comparison with our CHD8 KO samples, we applied the same criteria used in the original study for identifying DEGs (log2 (fold change) $\geq 1$ and $p \leq 0.05$ ).

\section{Statistics}

To determine if DEGs overlapped with or were significantly enriched with a specific gene set, 12,893 expressed genes in our samples were used as background for Fisher's exact test. Statistics tests were conducted in R (http://www.R-project.org/). Common genes between two gene lists were input to DAVID (beta 6.8) for GO term analysis.

\section{Results}

RNA-seq was carried out on cerebral organoids derived from $\mathrm{CHD} 8 \mathrm{KO}$ iPS cells; two isogenic controls $\left(\mathrm{CHD}^{+/+}\right)$ and four heterozygotes $\left(\mathrm{CHD}^{+/-}\right)$. The $\mathrm{CHD} 8^{+/-}$samples contain a CHD8 $\mathrm{KO}$ allele with either a 10-base pair deletion (clones $\mathrm{A}, \mathrm{B}$, and $\mathrm{C}$ ) or a 2-base pair deletion (D), both of which lead to frameshift mutations and premature stop signals in exon 1 [8]. The KO lines were derived from $\mathrm{CHD}^{+/+} \mathrm{A}$; the other control, $\mathrm{CHD}^{+/+} \mathrm{B}$, was a different iPS cell clone from the same subject. We previously showed that heterozygous $\mathrm{KO}$ leads to a $\sim 50 \%$ reduction in CHD8 protein [8]. Similarly, quantitative immunohistochemistry showed a $54 \%$ decrease in CHD8 immunoreactivity in $\mathrm{CHD}^{+/-}$compared with $\mathrm{CHD8^{+- }}$ organoids (analyzed in 15 random fields, $p=7.2 \mathrm{E}-13$ ) (Additional file 2: Figure S1).

The RNA-seq data quality is shown in Additional file 3: Table S1. A total of 12,893 expressed genes were detected, and DESeq2 was used to identify DEGs, as described in detail in the "Methods" section. Using a cutoff of $\mathrm{FDR}<0.05$, there were $559 \mathrm{DEGs}$ when the $\mathrm{CHD}^{+/+}$ organoids were compared with $\mathrm{CHD}^{+/-} ; 288$ genes increased in the KO, 271 decreased. The DEGs separated our sample into two groups, as seen in the heat map shown in Fig. 1a. The entire list of DEGs is in Additional file 4: Table S2. CHD8 mRNA itself was not significantly differentially expressed based on our RNA-seq analysis. The $\mathrm{KO}$ allele, however, showed a much lower level of expression than the WT allele in the organoids (Additional file 1), probably due to nonsense mediated decay. Overall, though, the decrease in CHD8 mRNA was not proportional to the decrease in CHD8 protein, similar to our observations in NPCs [8]. The relatively imprecise correlation between mRNA and protein levels is found for many genes and can be due to a number of factors [60]. However, the mechanism of the discrepancy between CHD8 mRNA and protein is not known and will require further investigation.

We should also point out that among the three CHD8 alternatively spliced transcripts in the GENCODE annotation, the two containing the exon 1 accounted for 70 $\sim 80 \%$ of the CHD8 transcripts in the WT organoids and $60-70 \%$ in the $\mathrm{CHDS}^{+-}$, based on our RNA-seq data (Additional file 1).

Of the 559 DEGs, 203 have CHD8 binding sites in their promoters, using data from a ChIP-seq study carried out on NPCs by Sugathan et al. (see Additional file 4: Table S2, column I) [28]. The finding that such a large fraction of DEGs are direct targets of CHD8 confirms the validity of our RNA-seq findings. However, it also shows that many downstream genes are indirect targets of 


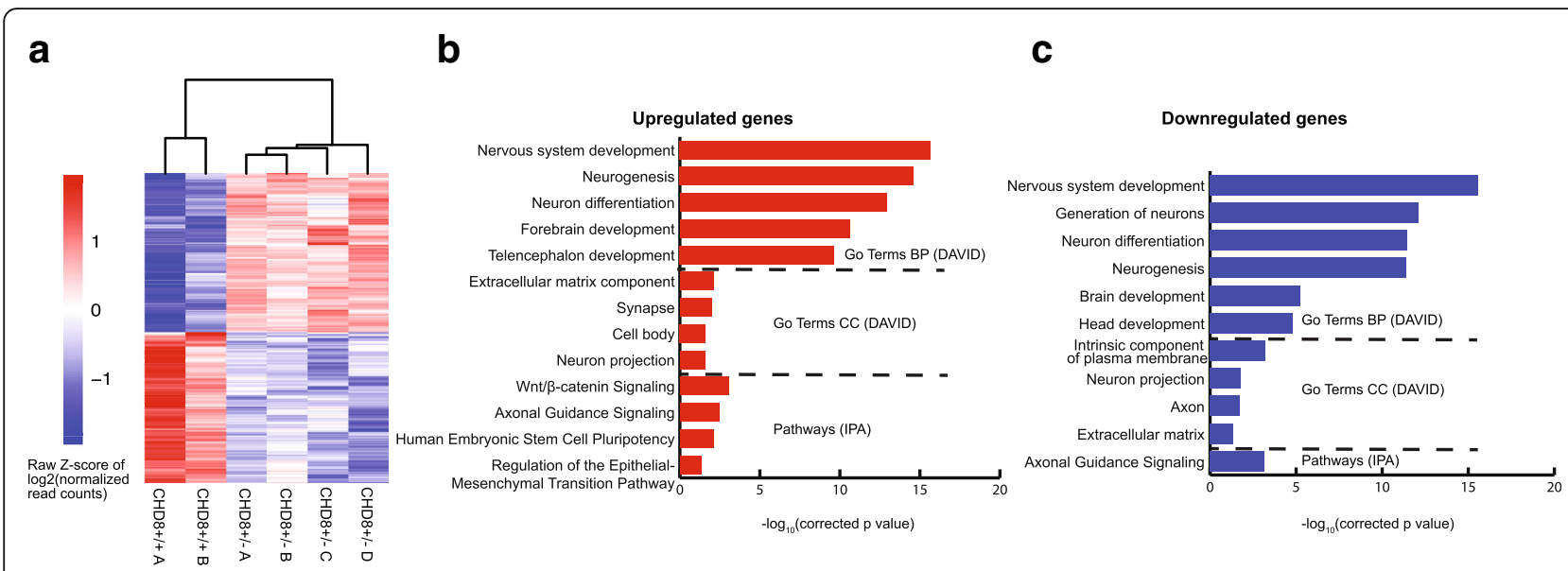

Fig. 1 Heat map and summary of GO terms and pathways. a The heat map shows differentially expressed genes between controls $\left(\mathrm{CHD} 8^{+/+}\right)$and heterozygous knockouts $\left(\mathrm{CHD}^{+/-}\right)$. Enriched GO terms by DAVID (top) and pathways by IPA (bottom) for upregulated (b) and downregulated (c) genes in $\mathrm{CHD}^{+/-}$organoids. $P$ values were corrected by the Benjamini method [147]

CHD8, most likely through the actions of other genes coding for transcription factors and chromatin-remodeling proteins that are directly affected by CHD8, such as TCF4, POU $3 F 2$, SMARCA4, SOX2, and PAX6. This result is consistent with our previous report [8].

The software DAVID was used to identify enriched GO pathways in DEGs using 12,893 expressed genes as background [49]. IPA was used for canonical pathways and disease association. The top GO terms (Biological Process, (BP)) for genes that were upregulated in the CHD8 KO organoids were nervous system development, neurogenesis, neuron differentiation , and forebrain development; the top GO:BP terms for downregulated genes were nervous system development, generation of neurons, and neuron differentiation (Fig.1b, c; Additional file 5: Table S3). Genes coding for components of the ECM were the top cellular component (CC) GO terms for upregulated DEGs, and among the top eight for downregulated DEGs, similar to our previous findings using monolayer neurons [8]. The top enriched IPA canonical pathways were $\mathrm{Wnt} / \beta$-catenin signaling and axonal guidance for upregulated genes and axonal guidance for downregulated genes. An enrichment of DEGs involved in Wnt/ $\beta$-catenin signaling is similar to that found in our previous transcriptome analysis on $\mathrm{CHD}^{+/-}$NPCs and neurons [8], as well as findings by other investigators [10, 20, 24], firmly establishing that altered expression of $C H D 8$ disrupts this critical signaling pathway.

As a complementary analysis, we also applied TopHat and DESeq2 for aligning the RNA-seq reads and for DEG analysis, respectively, as we previously carried out [8]. This resulted in 811 DEGs (Additional file 4: Table S2 sheet 2), 534 of which were included in the DEG list from Kallisto/ DESeq2 analysis. GO analysis showed an enrichment of similar GO terms in the two DEG lists, with "neuron system development" being the top term for both upregulated and downregulated genes (Fig. 1).

Overall, the findings show that CHD8 directly, or indirectly through effects on other transcription factors and chromatin regulators, regulates a program of gene expression that affects critical aspects of brain development (e.g., neurogenesis, neuron differentiation, and axonal guidance).

\section{Comparison between organoid data and NPCs and monolayer neurons}

We compared current transcriptome data with our previous study using NPCs and monolayer neurons [8]. There is a significant overlap between the studies, with nearly $50 \%$ of DEGs in organoids showing differential expression in NPCs and neurons (neurons odds ratio $[\mathrm{OR}]=2.88, p<2.2 \mathrm{E}-16 ; \mathrm{NPCs} \mathrm{OR}=4.44, p<2.2 \mathrm{E}-16$, Fisher's test) (Fig. 2; see Additional file 4: Table S2 for overlapping genes). The top GO terms for overlapping genes were neuron differentiation and neurogenesis, respectively, which is consistent with the main pathway findings in organoids described above.

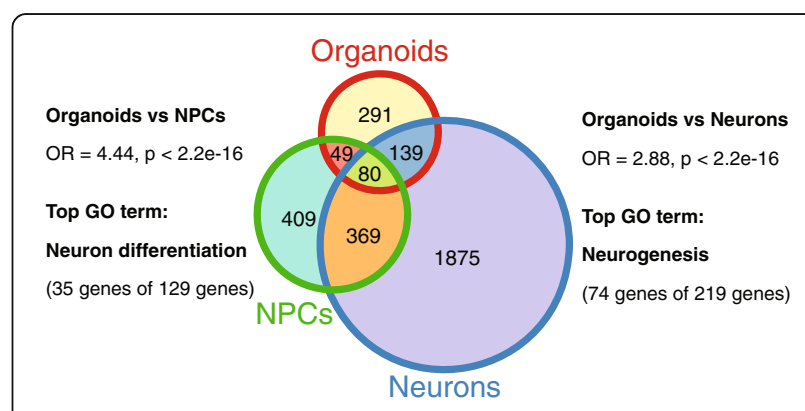

Fig. 2 Overlapping DEGs in organoids compared with NPCs and monolayer neurons from previous study [8] 


\section{qPCR validation}

We validated several RNAs of interest by qPCR using the $2^{-\Delta \Delta \mathrm{Ct}}$ relative expression method: SOX2, PAX6, TCF4, CNTNAP2, HMGA2, RELN, MEG3, DLX6-AS1, and $C R N D E$ (Fig. 3). These genes were chosen because of their known importance in brain development and disease. SOX2 and PAX6 code for transcription factors that influence neural stem cell growth and brain development [60,61]. TCF4 codes for a transcription factor; both common and rare variants have been implicated in the etiology of SZ, BD, ASD, and developmental delay $[34,36,37,62]$. CNTNAP2 codes for a member of the neurexin family of presynaptic proteins; it too has been implicated in the pathogenesis of SZ and ASD [63-67]. HMGA2 codes for a non-histone DNA-binding protein that has been implicated in regulating brain growth and head circumference; increased expression was found in our previous transcriptome analysis $[8,68] . R E L N$ codes for reelin, a key secreted ECM protein involved in neuronal migration during brain development [69-72]. Altered expression has been found in SZ and ASD [72-77]. As seen in Fig. 4, reelin is expressed throughout the organoids, in fields of neurons as well as in the zone of proliferating radial glia progenitors found in these structures $[39,40,42]$. MEG3 is a maternally expressed imprinted gene that acts as a tumor suppressor gene in a number of malignancies [21, 78-82]. DLX6-AS1 and CRNDE will be

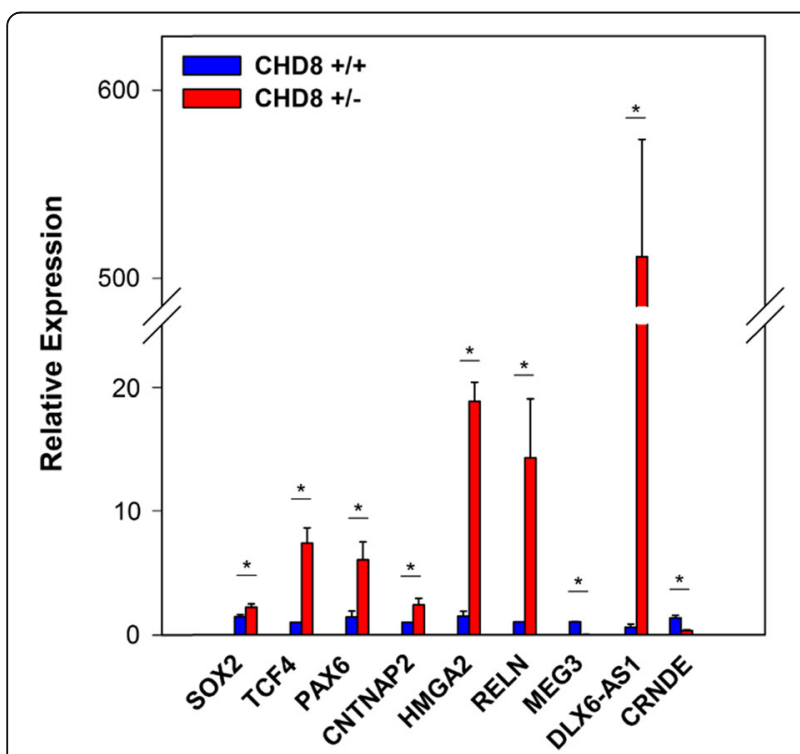

Fig. 3 Validation of selected DEGs by qPCR. The RNA samples used in the RNA-seq were used for this analysis. Samples were analyzed in triplicate as described in "Methods" section and Additional file 1: Supplemental methods. Significant differences between control and $\mathrm{KO}$ are denoted by an asterisk $(*)$. The $p$ values derived by Student's $t$ test were as follows: SOX2, 0.047; TCF4, 0.004; HMGA2, 0.00005; PAX6, 0.02; RELN, 0.02; CNTNAP2, 0.04; DLX6-AS1, 0.0001; MEG3, 0.00002 discussed below. qPCR analysis validated the RNA-seq findings for each of these genes.

\section{Top DEGs and overlap with organoid transcriptome in idiopathic ASD}

Two of the top three DEGs in $C H D 8^{+/-}$cerebral organoids were DLX6-AS1 and DLX1, which increased $\sim 39$ and 13-fold respectively (Additional file 4: Table S2). They were hardly expressed in controls. DLX6-AS1 (also known as EVF2) forms a complex with DLX1 and DLX2 proteins that subsequently regulates GABAergic interneuron development by increasing $D L X 5$ and $D L X 6$ gene expression [43, 83-86]. Strikingly, in a study by Mariani et al., DLX6-AS1 was also the top DEG in a transcriptome analysis carried on day 11 cerebral organoids derived from members of a family with idiopathic ASD, and the 6th top DEG in day 31 organoids [42]. $D L X 1$ was differentially expressed at both time points as well.

In addition to DLX6-AS1, among the top 15 DEGs in $\mathrm{CHDS}^{+-}$cerebral organoids, 11 were also DEGs in the Mariani et al. study in either or both of their day 11 and day 31 organoids, and the direction of change was the same (Table 1). This included genes involved in brain development, several of which have been implicated in ASD, including FZD8, PAX6, SLC1A3, EOMES (TBR2), and MPPED1.

Aside from the top DEGs, overall, there was a significant overlap in DEGs between our $\mathrm{CHDS}^{+/-}$organoids and idiopathic ASD day 11 and day 31 organoids in the Mariani et al. study (Fig. 5; Additional file 6: Table S4). Similarly, significant overlap was detected in a comparison of DEGs from our previous study on NPCs and monolayer neurons with idiopathic ASD organoids. The most significant overlap was found in the comparison between $\mathrm{CHD}^{+/-}$organoids and day 31 organoids from the Mariani et al. study, which showed that $23 \%$ of DEGs were the same $(131 / 560 ; \mathrm{OR}=5.04 ; p=1.34 \mathrm{E}-40)$. The top GO terms for overlapping genes were nervous system development, neuron differentiation, and neurogenesis for day 11 and day 31 organoids (Additional file 6: Table S4).

Although the degree of overlap is impressive, a key difference in our respective studies is that FOXG1 was a top, upregulated DEG in the idiopathic ASD organoids, but not in the $\mathrm{CHDS}^{+/-}$samples; reducing FOXG1 by RNAi rescued the over-abundance of GABAergic interneurons found in the idiopathic ASD organoids [42]. Conversely, TCF4, a major DEG in all of our $C H D 8^{+/-}$ samples, was not differentially expressed in the idiopathic ASD organoids. This suggests that unique expression changes can occur in key genes despite the extensive overlap in transcriptomes, which could conceivably limit the full therapeutic impact of novel drugs that target common pathways. 

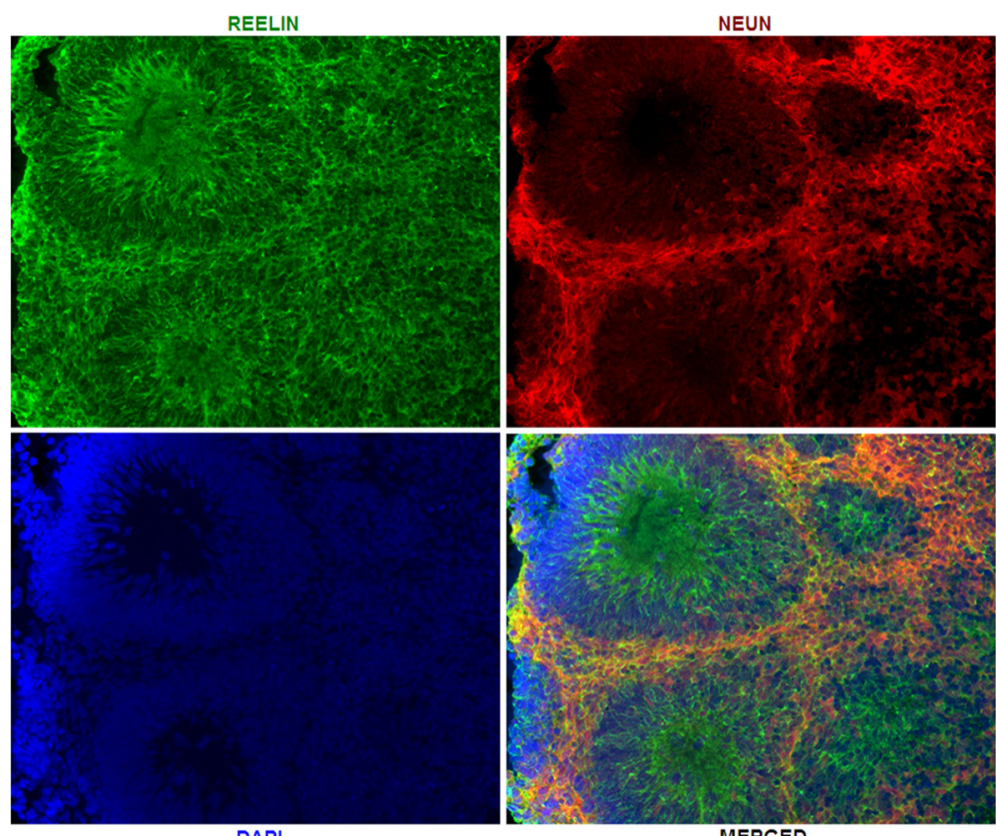

Fig. $4 \mathrm{Immunohistochemistry.} \mathrm{RELN} \mathrm{and} \mathrm{the} \mathrm{neuronal} \mathrm{marker} \mathrm{NeuN} \mathrm{were} \mathrm{visualized} \mathrm{as} \mathrm{described} \mathrm{in} \mathrm{Additional} \mathrm{file} \mathrm{1:} \mathrm{Supplemental} \mathrm{methods.} \mathrm{The}$ $\mathrm{DAPI}+$ tubular structures are zones of proliferating radial glia progenitors. NeuN+ cells are fields of neurons surrounding the radial glia progenitors

\section{CHD8 haploinsufficiency and WNT- $\beta$-catenin signaling}

$\mathrm{WNT} / \beta$-catenin signaling is a key pathway in the developing brain that is dysregulated in neuropsychiatric disorders, as well as in various cancers [4, 10, 12-23]. Thus, the finding that $C H D 8$ binds to $\beta$-catenin, inhibiting its transcriptional effects, $[10,20]$ is relevant to the role of CHD8 in both neuropsychiatric and neurodevelopmental disorders, as well as cancers. Recently, however, CHD8 was shown to be a positive regulator of $\mathrm{WNT} / \beta$-catenin signaling in human NPCs [87]. Among the neuropsychiatric disorders, $\mathrm{WNT} / \beta$-catenin is particularly relevant to BD because lithium salts, which are used to treat the condition, inhibit GSK3 $\beta$, which would be expected to result in an increase in $\beta$-catenin levels (constitutive GSK3 $\beta$

Table 1 Top 15 DEGs in $\mathrm{CHD}^{+/-}$vs idiopathic ASD cerebral organoids

\begin{tabular}{|c|c|c|c|c|c|c|}
\hline $\mathrm{CHD}^{+/-}$ & Log2FC & Padj & Log2FC_11 & FDR & Log2FC_31 & FDR \\
\hline DLX6-AS1 & 5.34 & $3.85 \mathrm{E}-86$ & 4.72 & $1.70 \mathrm{E}-75$ & 4.61 & 7.03E-37 \\
\hline ARMCX1 & -2.48 & 4.47E-34 & NS & NS & NS & NS \\
\hline DLX1 & 3.84 & $5.97 E-32$ & 2.14 & $1.38 \mathrm{E}-11$ & 1.35 & $8.69 \mathrm{E}-03$ \\
\hline FZD8 & 2.21 & 1.17E-26 & 1.19 & $2.35 \mathrm{E}-04$ & NS & NS \\
\hline CPNE6 & 3.55 & $1.47 \mathrm{E}-24$ & NS & NS & NS & NS \\
\hline PAX6 & 2.03 & $2.05 E-22$ & NS & NS & 1.29 & $2.23 \mathrm{E}-04$ \\
\hline SLC1A3 & 1.61 & $2.05 E-22$ & 1.13 & $9.21 \mathrm{E}-06$ & NS & NS \\
\hline EOMES & 3.10 & $9.04 \mathrm{E}-22$ & 2.96 & $1.85 \mathrm{E}-17$ & 2.79 & 1.17E-06 \\
\hline MPPED1 & 2.92 & $3.31 \mathrm{E}-21$ & 1.57 & 4.50E-05 & 1.41 & $7.29 \mathrm{E}-03$ \\
\hline COL25A1 & 2.67 & $4.42 \mathrm{E}-21$ & NS & NS & NS & NS \\
\hline SCGN & 3.22 & $9.46 \mathrm{E}-20$ & 2.15 & $1.25 \mathrm{E}-06$ & 1.37 & 1.57E-02 \\
\hline STK17B & 2.08 & $9.46 \mathrm{E}-20$ & NS & NS & NS & NS \\
\hline LIX1 & 2.14 & 8.70E-19 & NS & NS & 0.83 & $2.53 \mathrm{E}-02$ \\
\hline BCL11B & 1.63 & $7.21 \mathrm{E}-18$ & 0.95 & 4.85E-02 & 2.16 & $2.36 \mathrm{E}-12$ \\
\hline SHISA2 & 2.14 & $2.29 \mathrm{E}-17$ & 1.41 & $1.58 \mathrm{E}-06$ & NS & NS \\
\hline
\end{tabular}

Top 15 DEGs in $\mathrm{CHD}^{+/-}$are shown in left columns with fold change (FC) and $p$ value adjusted for genome-wide significance (padj). The right columns show the FC and false discovery rate (FDR) values for the same genes, derived from the Mariani et al. study [42]. Log2FC_11 is from day 11 cerebral organoids, while log2FC_31 is from day 31 organoids. Note that DLX6-AS1 was the top DEG in day 11 organoids and the 6th top DEG in day 31 organoids 


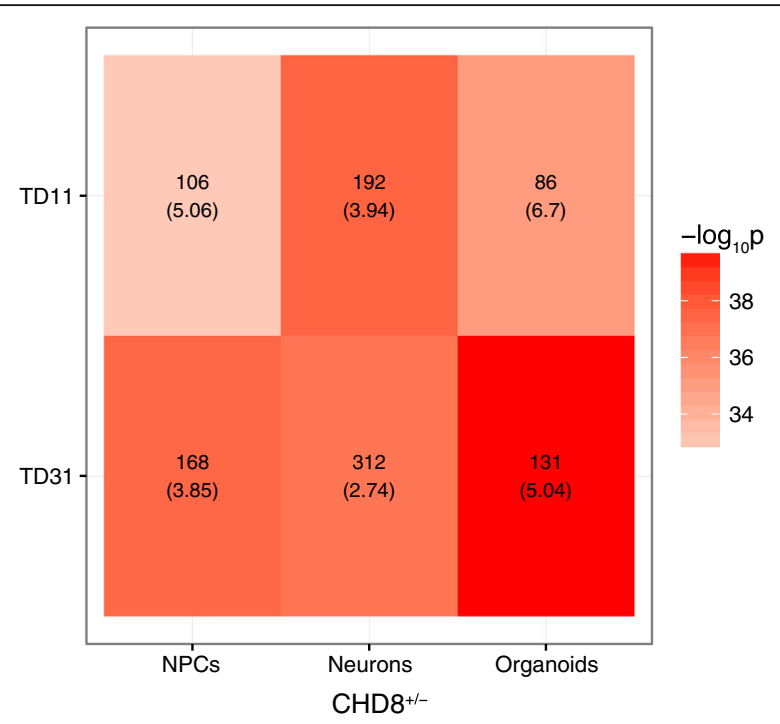

Fig. 5 Overlap in DEGs between CHD8 and idiopathic ASD organoids. CHD8 KO DEGs were compared with DEGs from day 11 and day 31 organoids (TD11, TD31) derived from individuals with idiopathic ASD [42]. The number in each panel shows the number of overlapping genes, which can be seen in Additional file 5: Table S4. The numbers in parentheses are the odds ratios. Color represents $p$ value from Fisher's test

activity leads to $\beta$-catenin degradation) [88-92]. With these considerations in mind, as well as our finding that $\mathrm{WNT} / \beta$-catenin signaling is the top pathway for upregulated DEGs in $\mathrm{CHD}^{+/-}$organoids (Fig. 1b, c), we compared our DEG list with those found in a recent study by Mertens et al. in which transcriptome analyses were carried out in iPS cell-derived neurons from BD patients who were clinically responsive or not responsive to lithium [59]. In addition, we also evaluated the DEG list derived from NPCs and monolayer neurons from our previous study, which also showed that $\mathrm{WNT} / \beta$-catenin was a top pathway among DEGs in monolayer neurons [8]. Using the same criteria for defining DEGs in the Mertens et al. study (log2 fold change $\geq 1$ and $p \leq 0.05$ ), significant overlap was found in each comparison (Fig. 6; Additional file 7: Table S5). Note that only $30-50 \%$ of DEGs in the Mertens et al. study were expressed in our organoids, which is probably due to differences in the differentiation protocols used. However, the most significant overlap ( $p \leq 5.73 \mathrm{E}-23$; $\mathrm{OR}=4.64)$ occurred in the comparison between our $\mathrm{CHD8}^{+/-}$DEGs and the lithium nonresponders in Mertens et al. (Interestingly, DLX6-AS1 and $D L X 1$ were in this group of overlapping DEGs; Additional file 7: Table S5).

The top GO terms for overlapping genes were similar for both the $\mathrm{Li}$ non-responder and $\mathrm{Li}$ responder vs $\mathrm{CHD}^{+/-}$ organoid DEGs; nervous system development, neuron differentiation, and neurogenesis (Additional file 7: Table S5). However, one GO term found exclusively in the former was axonogenesis. Although lithium is extremely useful in a substantial proportion of $\mathrm{BD}$ patients, it is also used on occasion to treat patients diagnosed with SZ and ASD, especially as adjunctive therapy for those with a mood component and for refractory patients to augment the effect of anti-psychotic medications [88, 93-98]. Although there was a greater association to the lithium non-responder group, considering that there is significant overlap with the lithium-responder group as well could have therapeutic implications.

\section{ASD and SZ candidates in $\mathrm{CHD8}^{+/-}$DEGs}

The protein-coding DEGs were considered for their over-representation of SZ and ASD candidate genes using a variety of sources, as described in the "Methods" section and our previous study [8]. As seen in Fig 7, among the $\mathrm{CHD}^{+/+}$vs $\mathrm{CHD}^{+/-}$DEGs, there was significant enrichment of ASD candidate genes in the SFARI, AutismKB, and Willsey ASD datasets, and an even more significant enrichment of SZ candidates in the SZGene and SZ GWAS lists (see Additional file 8: Table S6 for complete list). Enriched GO terms were identified for the overlapping genes in three of these datasets: SFARI, AutismKB, and SZ GWAS. The top GO terms for SFARI and AutismKB were similar; forebrain development, telencephalon development, and pallium development were the most significant (Additional file 8: Table S6). For the SZ GWAS data set, the top GO terms for overlapping genes were somatodendritic compartment, synapse, neuron projection, cell body, and axon. The differences between the ASD and SZ sets of overlapping genes reflect the observation that CHD8 haploinsufficiency is a risk factor for both groups of conditions and suggest that disruption of different molecular pathways is involved in the increased risk and differences in clinical presentation.

\section{DEGs involved in head circumference/brain volume}

Patients with loss of function CHD8 mutations typically have large head circumferences, a finding confirmed in a zebrafish model $[2,3]$. In our previous study, 7 out of 12 genes (TESC, DDR2, HMGA2, SBNO1, FAT3, BCL2L1, and MSRB3) implicated in brain size in genome-wide association studies were differentially expressed in $\mathrm{CHDS}^{+/-}$NPCs and neurons $[8,68,99,100]$. However, among these genes, only HMGA2 (high mobility group AT-hook 2) expression was similarly affected in CHD 8 KO organoids. In addition, one gene, DCC (deleted in colorectal carcinoma), which was not differentially expressed in the previous study, was significantly decreased in $\mathrm{CHDS}^{+-}$organoids. Both the HMGA2 and DCC gene loci have CHD8 binding sites [28]. The findings show unequivocally that HMGA2 expression is regulated by CHD8. 


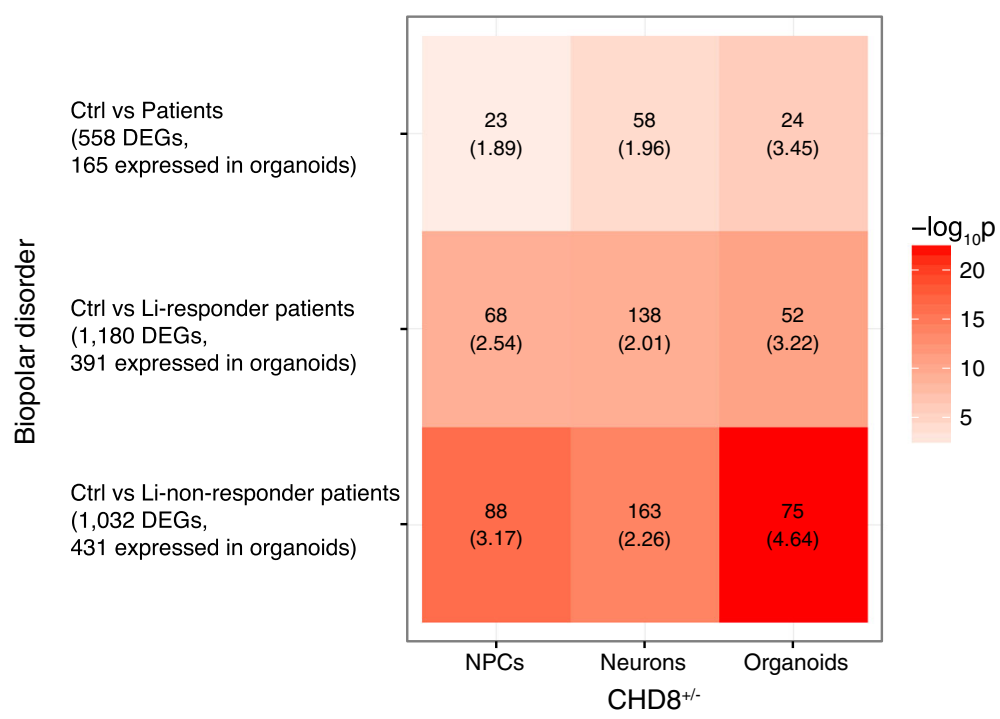

Fig. 6 Overlap in DEGs between CHD8 KO and BD neuronal cells. CHD8 KO DEGs from the current study (organoids) and our previous study (NPCS, neurons) [42] were compared with DEGs found in neurons derived from lithium responder and lithium non-responder patients with BD, as described in "Methods" section. The number in each panel shows the number of overlapping genes, which can be seen in Additional file 6: Table S5. The numbers in parentheses are the odds ratios

\section{ncRNAs}

In addition to $D L X 6$ - $A S$, there were 19 other non-coding RNAs (ncRNAs) that were differentially expressed in $\mathrm{CHD}^{+/-}$organoids (Table 2), of which 9 are CHD8 targets based on published ChIP findings [28]. Several of the differentially expressed ncRNAs we detected have been implicated in neuropsychiatric disorders. One is the RMST locus, which contains a microRNA involved in forebrain development through its modulation of $\mathrm{WNT} / \beta$-catenin signaling and has been found to regulate neurogenesis through an interaction with SOX2 [13, 101]. Another is MIAT (also known as GONAFU); RNA levels were found to be expressed at

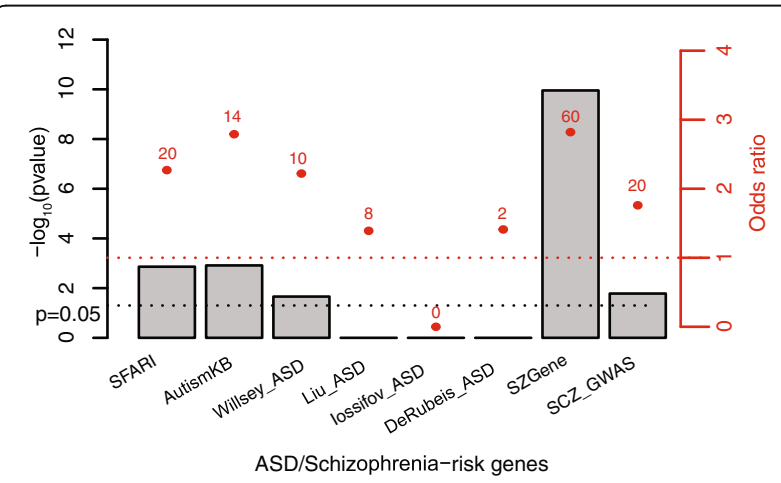

Fig. 7 Overlap between CHD8 KO DEGs and ASD and SZ candidate genes. CHD8 KO DEGs were evaluated for enrichment of ASD and SZ candidate genes. Bars represent $p$ value (Fisher's exact test, one-tailed), while red dots represent odds ratio of overlap. The number above each red dot shows the number of overlapping genes, which can be found in Additional file 7: Table S6 higher levels in parvalbumin GABAergic interneurons in SZ subjects [102] and have been found to regulate fear-related anxiety traits in mice [103]. MIAT also binds to several splicing factors and may affect splicing of the SZ-associated ERBB4 and DISC1 genes in response to neuronal activation [104]. Finally, $C R N D E$ expression is significantly elevated in iPS cell-derived neurons from patients with SZ who have 22q11.2 deletions [105]. Although the molecular effects of most ncRNAs have not been determined, many function at the gene expression level through their regulation of chromatin architecture and nuclear organization, which, if disrupted, could potentially alter neurodevelopmental molecular programs [43, 82, 104, 106-111].

\section{Discussion}

One of the most interesting characteristics of CHD8 is its diverse effect on several neuropsychiatric and neurodevelopmental disorders and cancer. Although ASD and cancer differ fundamentally in a key aspect regarding loss of function CHD8 mutations and disease in that the former are due to germline mutations, while the latter are usually somatic, it is not surprising that a chromatin and transcriptional regulator like CHD8 would play a role in both types of conditions. Indeed, in recently published pathway network analyses and sequencing studies, overlap was found for several ASD candidate genes and cancer [30, 112]. Correspondingly, germline mutations in NF1, which cause neurofibromatosis type I, often display autistic-like behaviors [113, 114]. The molecular genetic overlap suggests that some novel cancer therapies 
Table 2 Differentially expressed ncRNAs

\begin{tabular}{|c|c|c|c|c|}
\hline Gene_name & Gene_type & NPC_binding & Log2FC & Padj \\
\hline DLX6-AS1 & antisense & 0 & $5.34 \mathrm{E}+00$ & $3.85 \mathrm{E}-86$ \\
\hline EMX2OS & antisense & 0 & $1.10 \mathrm{E}+00$ & 3.79E-02 \\
\hline LINC00340 & lincRNA & 1 & $-7.78 \mathrm{E}-01$ & 1.54E-04 \\
\hline TERC & lincRNA & 0 & $-1.07 \mathrm{E}+00$ & $1.18 \mathrm{E}-03$ \\
\hline CRNDE & lincRNA & 1 & $-9.63 \mathrm{E}-01$ & 1.39E-02 \\
\hline MEG3 & lincRNA & 1 & $-1.24 \mathrm{E}+00$ & 1.39E-02 \\
\hline RMST & processed_transcript & 0 & $-1.23 E+00$ & $6.41 \mathrm{E}-07$ \\
\hline MIAT & processed_transcript & 1 & $-1.28 \mathrm{E}+00$ & $6.10 \mathrm{E}-06$ \\
\hline NEFL & processed_transcript & 0 & $-1.18 \mathrm{E}+00$ & $2.08 \mathrm{E}-04$ \\
\hline TMEM191A & processed_transcript & 0 & $-7.74 \mathrm{E}-01$ & 1.33E-02 \\
\hline SPPL2B & processed_transcript & 1 & $-6.41 \mathrm{E}-01$ & $2.32 \mathrm{E}-02$ \\
\hline SCARNA22 & sense_intronic & 0 & $-1.31 E+00$ & $1.56 \mathrm{E}-03$ \\
\hline SNHG3 & sense_intronic & 1 & $-7.94 \mathrm{E}-01$ & $1.41 \mathrm{E}-02$ \\
\hline SOX2-OT & sense_overlapping & 1 & $9.29 \mathrm{E}-01$ & $9.81 \mathrm{E}-04$ \\
\hline SNORA31 & snoRNA & 0 & $-1.03 E+00$ & 2.41E-02 \\
\hline SNORA7B & snoRNA & 1 & $-1.03 E+00$ & 3.30E-02 \\
\hline SCARNA13 & snoRNA & 0 & $-7.08 \mathrm{E}-01$ & 3.77E-02 \\
\hline SNORA73B & snoRNA & 1 & $-7.89 \mathrm{E}-01$ & 4.61E-02 \\
\hline RNU2-59P & snRNA & 0 & $-9.94 \mathrm{E}-01$ & $1.76 \mathrm{E}-02$ \\
\hline RNU6-15P & snRNA & 0 & $-1.07 \mathrm{E}+00$ & 4.99E-02 \\
\hline
\end{tabular}

currently being developed, especially those that target the epigenome might be beneficial in treating subgroups of individuals with neurodevelopmental disorders $[112,115]$.

The mechanisms by which loss of function CHD8 mutations increase cancer risk are likely to be multifactorial. Part of the effect appears to be due to the direct interaction between $\mathrm{CHD} 8$ protein with $\beta$-catenin and p53, and an effect on the cell cycle [2, 24, 25]. An effect mediated by $\beta$-catenin is given additional support by our transcriptome analysis. In addition, based on our findings, CHD8 may also contribute to malignant transformation indirectly through its effects on other genes, which were found to be differentially expressed in this study and have been implicated in malignant transformation, such as SMARCA4, POU4F1, ARMCX1, HMAG2, DCC, and ZNF132 (Additional file 4: Table S2) [116, 117]. Several of the differentially expressed ncRNAs we show on Table 2 have also been found to be associated with cancer development, including TERC, which codes for the RNA component of telomerase; telomere shortening is a feature of malignant transformation and aging [118]. MEG3, as noted above, CRNDE, LINC00340, and RMST (rhabdomyosarcoma 2 associated transcript) is also found in various cancers [118-124]. These findings suggest that the effect of CHD8 on malignant transformation is multifactorial and not simply due to a direct interaction with the $\mathrm{Wnt} / \mathrm{\beta}$-catenin signaling pathway.
Similarly, the role of $C H D 8$ on neuropsychiatric and neurodevelopmental disorders is multifactorial, with both direct effects on downstream targets, such as $\beta$-catenin, and indirect effects mediated by dysregulated expression of other transcription factors and chromatin remodelers. The best example of this is the SZ and BD candidate gene $T C F 4$, which codes for a basic helix-loop-helix transcription factor [125]. CHD8 haploinsufficiency leads to a $\sim 2$ fold increase in TCF4 expression in cerebral organoids and NPCs and neurons (Additional file 4: Table S2) [8]. In addition, pathway analysis showed extensive overlap with TCF4 targets, and CHD8 binds to the TCF4 gene locus $[8,28]$. An increase in TCF4 expression has also been found in iPS cell neurons and fibroblasts derived from SZ patients [126, 127]. In addition, TCF4 is upregulated by loss of function mutations in the SZ candidate MIR137, and overexpression in the forebrain of mice leads to cognitive impairments and deficits in pre-pulse inhibition [128-130]. Overall, the findings strongly suggest that TCF4 and CHD8 cooperate to influence neuronal differentiation and brain development, and that TCF4 overexpression is a key feature in SZ and BD.

On the other hand, loss of function TCF4 mutations have been found in patients with Rett syndrome-like phenotypes [131, 132], ASD [133] and Pitt-Hopkins syndrome, which is characterized by ASD, intellectual 
disabilities, and microcephaly $[134,135]$. Thus, TCF4 gene dosage in either direction adversely affects brain development.

Other transcription factors and chromatin regulators that are significantly affected by CHD 8 haploinsufficiency that are also ASD and SZ candidate genes include POU $3 F 2$ and AUTS2. POU3F2 expression is significantly decreased in $\mathrm{CHDS}^{+/-}$in cerebral organoids, as well as in NPCs and neurons, while AUTS2 expression is significantly decreased in $\mathrm{CHDS}^{+/-}$in cerebral organoids and neurons, but not NPCs (Additional file 4: Table S2) [8]. POU $3 F 2$ codes for a member of the POU family of transcription factors, and has been implicated in SZ, and more recently in $\mathrm{BD}$, developmental delay, and intellectual disability $[136,137]$. Its critical role in neuronal differentiation is highlighted by the finding that it is one of the three factors, along with MYT1L and ASCL1, used in the direct reprogramming of fibroblasts into neurons [138]. AUTS2 codes for a chromatin-remodeling protein that functions as a component of the polycomb repressive complex 1 (PRC1); loss of function mutations can lead to ASD, SZ and intellectual disabilities [139-141]. Also, it is interesting to note, in the context of the ASD/ cancer connection, that AUTS2 is part of a translocation commonly found in childhood B cell precursor acute lymphoblastic leukemia [142].

One of the most interesting downstream targets of CHD8 we found regarding neurodevelopmental and neuropsychiatric disorders is the non-coding RNA, DLX6-AS1, which was the top DEG in our $\mathrm{CHDS}^{+/-}$ organoids, as well as organoids derived from a family with idiopathic ASD [42]. DLX6-AS1 overlaps with $D L X 6$ and is expressed in the opposite transcriptional orientation. In mice, a splice variant of Dlx6-as1 called Dlx6-as2 (evf2) cooperates with Dlx2 to increase the transcriptional activating function of the Dlx5/6 enhancer [143].

These findings suggest that CHD8 affects GABAergic interneuron development, by modulating $D L X$ gene expression. Consistent with this idea is the finding that several genes, in addition to $D L X 1$, involved in cerebral cortex GABAergic interneuron differentiation, $F E Z F 2$, $A R X$, and CNTN2, were differentially expressed in $\mathrm{CHD}^{+/-}$organoids (Additional file 4: Table S2). Statistically, the enrichment of genes involved in cerebral cortex GABAergic interneuron differentiation only achieved a trend toward significance $(p=3.6 \mathrm{E}-3$; padj $=5.8 \mathrm{E}-2)$, which could be due to the relatively small sample size. Abnormalities in cortical GABA interneuron function, in particular, parvalbumin positive and somatostatin positive interneurons have been found in SZ and ASD [144-146].

It should be noted that a limitation of this study is that it is based on a knockout carried out on a single iPS cell line, so replication in other lines is critical. Nevertheless, our findings strongly support a major role of CHD8 on Wnt $/ \beta$-catenin signaling, and a connection between CHD8 and TCF4, and several other genes that have been implicated in neuropsychiatric and neurodevelopmental disorders, in particular, members of the $D L X$ gene family. In addition, the overlap we detected between the $\mathrm{CHDS}^{+/-}$transcriptome and the transcriptomes obtained in idiopathic ASD and BD shows that common molecular pathways exist in different clinical conditions caused by seemingly disparate candidate genes. Identifying such common pathways will facilitate drug discovery in these genetically heterogeneous disorders.

\section{Conclusions}

CHD8, which codes for a chromatin-remodeling factor, is mutated in a subgroup of patients with ASD and SZ. RNA-seq analysis of cerebral organoids derived from iPS cells that are heterozygous for a CHD8 knockout allele, and isogenic controls, shows that CHD8 regulates the expression of other genes implicated in ASD and SZ, notably TCF4 and AUTS2. In addition, extensive overlap was observed for differentially expressed genes (DEGs) found in another study using organoids derived from a family with idiopathic autism, especially for genes involved in GABAergic interneuron development. These findings show molecular convergence of disparate genes involved in the development of ASD and SZ, an observation that will facilitate drug discovery. In addition, pathway analysis of DEGs revealed an enrichment of genes involved in regulating $\mathrm{Wnt} / \beta$-catenin signaling, a druggable pathway.

\section{Additional files}

Additional file 1: Supplemental methods (DOCX $153 \mathrm{~kb}$ )

Additional file 2: Figure S1. (1) Immunohistochemistry (IHS) of contro organoid section showing GABA immunoreactivity (GABAergic neurons) in a field of MAP2+ neurons. (2) IHS showing GABA and VGLUT2+ (glutamatergic) neurons. (3). quantitative IHS. CHD8 protein was quantified as described in "Methods" section comparing a control organoid $\left(\mathrm{CHD}^{+/+}\right)$ with a heterozygous $\mathrm{CHD} 8 \mathrm{KO}$ organoid $\left(\mathrm{CHD}^{+/-}\right)$. The images were captured using the same parameters, such as exposure times, for each fluorescence channel was the same for the $\mathrm{CHD}^{+/+}$and $\mathrm{CHD}^{+/-}$samples. Images edited in power point using the Picture Tools option were adjusted to the same brightness and contrast levels in $\mathrm{CHD}^{+/+}$and $\mathrm{CHD}^{+/-}$sections for CHD8 immunoreactivity and for Tuj1 reactivity. (PDF 1507 kb)

Additional file 3: Table S1. Summary of RNA-seq quality and number of differentially expressed genes. (DOCX $14 \mathrm{~kb}$ )

Additional file 4: Table S2. old change and level of significance for all genes in RNA-seq analysis: sheet1, results from Kallisto/DESeq2; sheet2, results from TopHat/DESeq2. Log2 fold change is heterozygote/control; pval is uncorrected $p$ value; padj is adjusted $p$ value for genome-wide significant. Bold type highlights differentially expressed genes at padj $<0.05$. NPC binding is based on Sugathan et al. [28]. Log2 fold changes and $p$ values from previous findings in NPCs and monolayer neurons are also shown [8]. (XLSX 8994 kb) 
Additional file 5: Table S3. Enriched gene ontology (GO) terms for DEGs: Sheet 1, upregulated DEGs; Sheet 2, downregulated DEGs; Sheet 3, IPA canonical pathways. (XLSX $62 \mathrm{~kb}$ )

Additional file 6: Table S4. Lists of overlapping DEGs between CHD8 KO and idiopathic ASD organoids (sheet 1). Gene ontologies for overlapping genes between CHD8 KO and idiopathic ASD organoids days 11 and 31 (sheets 2 and 3, respectively). (XLSX $58 \mathrm{~kb}$ )

Additional file 7: Table S5. List of overlapping DEGs between CHD8 KO organoids, NPCs and neurons, and non-responder and lithium (Li) responder patients with $\mathrm{BD}$ (sheet 1). Gene ontologies for overlapping genes between CHD8 KO and Li non-responders and Li responders (sheets 2 and 3, respectively). (XLSX $22 \mathrm{~kb}$ )

Additional file 8: Table S6. Lists DEG from CHD8 KO organoids, NPCs, and neurons that overlap with ASD and SZ candidate genes (sheet 1). Gene ontologies for overlapping genes between CHD8 KO and the SZGWAS, AutismKB, and SFARI databases (sheets 2-4, respectively). (XLSX $46 \mathrm{~kb}$ )

\section{Abbreviations}

ASD: Autism spectrum disorders; BD: Bipolar disorder; CHD8: Chromodomain helicase DNA-binding protein 8; DEG: Differentially expressed gene; DLX: Distal-less homeobox; ECM: Extracellular matrix; GO: Gene ontology; GWAS: Genome-wide association study; HLA: Human leukocyte antigen; IHC: Immunohistochemistry; IPA: Ingenuity pathway analysis; iPS cell: Induced pluripotent stem cell; KO: Knockout; MHC: Major histocompatibility complex; NPC: Neural progenitor cell; NSC: Neural stem cell; O.C.T: Optimal cutting temperature; OR: Odds ratio; Padj: Adjusted $p$ value; PCR: Polymerase chain reaction; Pval: $P$ value; QPCR: Quantitative real-time $P C R$; SZ: Schizophrenia; TPM: Transcripts per kilobase per million reads mapped; WT: Wild type

\section{Acknowledgements}

The authors would like to thank Wenjun Guo and Zheng Zhang for the CHD8 $\mathrm{KO}$ vectors and staff at the Cellular and Molecular Neuroimaging Core of the Rose F. Kennedy IDD research center at the Albert Einstein College of Medicine (Dr. Kostantin Dobrenis, Kevin Fisher, and Andrew K. Smith) for their help with immunohistochemistry. The Core is supported by NIH grant HD071593.

\section{Funding}

This work was supported by grants from the National Institute of Mental Health (NIMH); MH099452 to DZ and MH099427 and MH087840 to HML. We are grateful to the New York State Department of Health (NYSTEM Program) for the shared facility grant support (C029154). This work was also supported in part by a grant to The Rose F. Kennedy Intellectual and Developmental Disabilities Research Center (RFK-IDDRC) from the Eunice Kennedy Shriver National Institute of Child Health \& Human Development (NICHD) at the $\mathrm{NIH}$ (1P30HD071593-01).

\section{Availability of data and materials}

RNA-seq data can be accessed at the Gene Expression Omnibus (GEO), (https://www.ncbi.nlm.nih.gov/geo/), accession number GSE85417.

\section{Authors' contributions}

PW contributed to the bioinformatics, data analysis, and manuscript preparation. RM contributed to the $\mathrm{qPCR}$, immunohistochemistry, and manuscript preparation. EP contributed to the iPS cell cultures, generated knockout lines, and organoid cultures. MK analyzed the knockout lines and contributed to the literature search. CB contributed to the immunohistochemistry. DZ contributed to the bioinformatics, data analysis, and manuscript preparation and conceived the experiment. $\mathrm{HL}$ contributed to the manuscript preparation and data analysis and conceived the experiment. All authors read and approved the final manuscript.

\section{Competing interests}

Some of the authors (P.W., E.P., D.Z., and H.L.) have a licensing agreement with Applied Biological Materials Inc. to distribute the CHD8 knockout lines. Applied Biomedical Materials did not read the current paper and had no role in data collection or data analysis. The other authors declare that they have no competing interests.

\section{Consent for publication}

Consent to publish findings and data was provided in the consent form, which was signed by all participants.

\section{Ethical approval and consent to participate}

The study and consent forms were approved by the Albert Einstein College of Medicine Institutional Review Board (IRB). Consent was obtained by a skilled member of the research team who had received prior human subjects training.

\section{Author details}

${ }^{1}$ Department of Genetics, Albert Einstein College of Medicine, 1300 Morris Park Ave, Bronx, NY, USA. ²Department of Psychiatry and Behavioral Sciences, Erciyes University School of Medicine, Kayseri, Turkey. ${ }^{3}$ Erciyes University School of Medicine, Kayseri, Turkey. ${ }^{4}$ Department of Neurology, Albert Einstein College of Medicine, 1300 Morris Park Ave, Bronx, NY, USA. ${ }^{5}$ Department of Neuroscience, Albert Einstein College of Medicine, 1300 Morris Park Ave, Bronx, NY, USA. 'Department of Medicine, Albert Einstein College of Medicine, 1300 Morris Park Ave, Bronx, NY, USA.

\section{Received: 22 August 2016 Accepted: 15 February 2017}

Published online: 11 March 2017

\section{References}

1. Neale BM, Kou Y, Liu L, Ma'ayan A, Samocha KE, Sabo A, Lin CF, Stevens C, Wang LS, Makarov V, Polak P, Yoon S, Maguire J, Crawford EL, Campbell NG, Geller ET, Valladares O, Schafer C, Liu H, Zhao T, Cai G, Lihm J, Dannenfelser R, Jabado O, Peralta Z, Nagaswamy U, Muzny D, Reid JG, Newsham I, Wu Y, Lewis L, Han Y, Voight BF, Lim E, Rossin E, Kirby A, Flannick J, Fromer M, Shakir K, Fennell T, Garimella K, Banks E, Poplin R, Gabriel S, DePristo M, Wimbish JR, Boone BE, Levy SE, Betancur C, Sunyaev S, Boerwinkle E, Buxbaum JD, Cook Jr EH, Devlin B, Gibbs RA, Roeder K, Schellenberg GD, Sutcliffe JS, Daly MJ. Patterns and rates of exonic de novo mutations in autism spectrum disorders. Nature. 2012;485(7397):242-5.

2. O'Roak BJ, Vives L, Girirajan S, Karakoc E, Krumm N, Coe BP, Levy R, Ko A, Lee C, Smith JD, Turner EH, Stanaway IB, Vernot B, Malig M, Baker C, Reilly B, Akey JM, Borenstein E, Rieder MJ, Nickerson DA, Bernier R, Shendure J, Eichler EE. Sporadic autism exomes reveal a highly interconnected protein network of de novo mutations. Nature. 2012;485(7397):246-50.

3. Bernier R, Golzio C, Xiong B, Stessman HA, Coe BP, Penn O, Witherspoon K, Gerdts J, Baker C, Vulto-van Silfhout AT, Schuurs-Hoeijmakers JH, Fichera M, Bosco P, Buono S, Alberti A, Failla P, Peeters H, Steyaert J, Vissers LE, Francescatto L, Mefford HC, Rosenfeld JA, Bakken T, O'Roak BJ, Pawlus M, Moon R, Shendure J, Amaral DG, Lein E, Rankin J, Romano C, de Vries BB, Katsanis N, Eichler EE. Disruptive CHD8 mutations define a subtype of autism early in development. Cell. 2014;158(2):263-76.

4. Krumm N, O'Roak BJ, Shendure J, Eichler EE. A de novo convergence of autism genetics and molecular neuroscience. Trends Neurosci. 2014;37(2):95-105.

5. McCarthy SE, Gillis J, Kramer M, Lihm J, Yoon S, Berstein Y, Mistry M, Pavlidis P, Solomon R, Ghiban E, Antoniou E, Kelleher E, O'Brien C, Donohoe G, Gill M, Morris DW, McCombie WR, Corvin A. De novo mutations in schizophrenia implicate chromatin remodeling and support a genetic overlap with autism and intellectual disability. Mol Psychiatry. 2014;19(6):652-8.

6. Talkowski ME, Rosenfeld JA, Blumenthal I, Pillalamarri V, Chiang C, Heilbut A, Ernst C, Hanscom C, Rossin E, Lindgren AM, Pereira S, Ruderfer D, Kirby A, Ripke S, Harris DJ, Lee JH, Ha K, Kim HG, Solomon BD, Gropman AL, Lucente D, Sims K, Ohsumi TK, Borowsky ML, Loranger S, Quade B, Lage K, Miles J, Wu BL, Shen Y, Neale B, Shaffer LG, Daly MJ, Morton CC, Gusella JF. Sequencing chromosomal abnormalities reveals neurodevelopmental loci that confer risk across diagnostic boundaries. Cell. 2012;149(3):525-37.

7. Marfella CG, Imbalzano AN. The Chd family of chromatin remodelers. Mutat Res. 2007;618(1-2):30-40.

8. Wang P, Lin M, Pedrosa E, Hrabovsky A, Zhang Z, Guo W, Lachman HM, Zheng D. CRISPR/Cas9-mediated heterozygous knockout of the autism gene CHD8 and characterization of its transcriptional networks in neurodevelopment. Mol Autism. 2015;6:55. 015-0048-, eCollection 2015.

9. de Dieuleveult M, Yen K, Hmitou I, Depaux A, Boussouar F, Bou Dargham D, Jounier S, Humbertclaude H, Ribierre F, Baulard C, Farrell NP, Park B, Keime C, Carriere L, Berlivet S, Gut M, Gut I, Werner M, Deleuze JF, Olaso R, Aude JC, Chantalat S, Pugh BF, Gerard M. Genome-wide nucleosome specificity and function of chromatin remodellers in ES cells. Nature. 2016;530(7588):113-6. 
10. Nishiyama M, Skoultchi Al, Nakayama Kl. Histone $\mathrm{H} 1$ recruitment by CHD8 is essential for suppression of the Wnt-beta-catenin signaling pathway. Mol Cell Biol. 2012;32(2):501-12.

11. Thompson BA, Tremblay V, Lin G, Bochar DA. CHD8 is an ATP-dependent chromatin remodeling factor that regulates beta-catenin target genes. $\mathrm{Mol}$ Cell Biol. 2008:28(12):3894-904.

12. Okerlund ND, Cheyette BN. Synaptic Wnt signaling-a contributor to major psychiatric disorders? J Neurodev Disord. 2011;3(2):162-74.

13. Caronia-Brown G, Anderegg A, Awatramani R. Expression and functional analysis of the Wnt/beta-catenin induced mir-135a-2 locus in embryonic forebrain development. Neural Dev. 2016;11(1):9. 016-0065-y.

14. Hatou S, Yoshida S, Higa K, Miyashita H, Inagaki E, Okano H, Tsubota K, Shimmura S. Functional corneal endothelium derived from corneal stroma stem cells of neural crest origin by retinoic acid and Wnt/beta-catenin signaling. Stem Cells Dev. 2013;22(5):828-39.

15. Elizalde C, Campa VM, Caro M, Schlangen K, Aransay AM, Vivanco M, Kypta RM. Distinct roles for Wnt-4 and Wnt-11 during retinoic acid-induced neuronal differentiation. Stem Cells. 2011;29(1):141-53.

16. Brennand KJ, Simone A, Jou J, Gelboin-Burkhart C, Tran N, Sangar S, Li Y, Mu Y, Chen G, Yu D, McCarthy S, Sebat J, Gage FH. Modelling schizophrenia using human induced pluripotent stem cells. Nature. 2011;473(7346):221-5.

17. Wellcome Trust Case Control Consortium. Genome-wide association study of 14,000 cases of seven common diseases and 3,000 shared controls. Nature. 2007;447(7145):661-78.

18. Hur EM, Zhou FQ. GSK3 signalling in neural development. Nat Rev Neurosci. 2010;11(8):539-51.

19. Mao Y, Ge X, Frank CL, Madison JM, Koehler AN, Doud MK, Tassa C, Berry EM, Soda T, Singh KK, Biechele T, Petryshen TL, Moon RT, Haggarty SJ, Tsai LH. Disrupted in schizophrenia 1 regulates neuronal progenitor proliferation via modulation of GSK3beta/beta-catenin signaling. Cell. 2009;136(6):1017-31.

20. Sawada G, Ueo H, Matsumura T, Uchi R, Ishibashi M, Mima K, Kurashige J, Takahashi Y, Akiyoshi S, Sudo T, Sugimachi K, Doki Y, Mori M, Mimori K. CHD8 is an independent prognostic indicator that regulates Wnt/beta-catenin signaling and the cell cycle in gastric cancer. Oncol Rep. 2013;30(3):1137-42.

21. Kim MS, Chung NG, Kang MR, Yoo NJ, Lee SH. Genetic and expressional alterations of CHD genes in gastric and colorectal cancers. Histopathology. 2011;58(5):660-8.

22. Tahara T, Yamamoto E, Madireddi P, Suzuki H, Maruyama R, Chung W, Garriga J, Jelinek J, Yamano HO, Sugai T, Kondo Y, Toyota M, Issa JP, Estecio MR. Colorectal carcinomas with CpG island methylator phenotype 1 frequently contain mutations in chromatin regulators. Gastroenterology. 2014;146(2):530-38.e5.

23. Damaschke NA, Yang B, Blute Jr ML, Lin CP, Huang W, Jarrard DF. Frequent disruption of chromodomain helicase DNA-binding protein 8 (CHD8) and functionally associated chromatin regulators in prostate cancer. Neoplasia. 2014;16(12):1018-27.

24. Nishiyama M, Oshikawa K, Tsukada Y, Nakagawa T, lemura S, Natsume T, Fan Y, Kikuchi A, Skoultchi Al, Nakayama Kl. CHD8 suppresses p53-mediated apoptosis through histone $\mathrm{H} 1$ recruitment during early embryogenesis. Nat Cell Biol. 2009;11(2):172-82.

25. Subtil-Rodriguez A, Vazquez-Chavez E, Ceballos-Chavez M, Rodriguez-Paredes M, Martin-Subero Jl, Esteller M, Reyes JC. The chromatin remodeller CHD8 is required for E2F-dependent transcription activation of S-phase genes. Nucleic Acids Res. 2014:42(4):2185-96

26. Ishihara K, Oshimura M, Nakao M. CTCF-dependent chromatin insulator is linked to epigenetic remodeling. Mol Cell. 2006;23(5):733-42.

27. Cotney J, Muhle RA, Sanders SJ, Liu L, Willsey AJ, Niu W, Liu W, Klei L, Lei J, Yin J, Reilly SK, Tebbenkamp AT, Bichsel C, Pletikos M, Sestan N, Roeder K, State MW, Devlin B, Noonan JP. The autism-associated chromatin modifier CHD8 regulates other autism risk genes during human neurodevelopment. Nat Commun. 2015:6:6404

28. Sugathan A, Biagioli M, Golzio C, Erdin S, Blumenthal I, Manavalan P, Ragavendran A, Brand H, Lucente D, Miles J, Sheridan SD, Stortchevoi A, Kellis M, Haggarty SJ, Katsanis N, Gusella JF, Talkowski ME. CHD8 regulates neurodevelopmental pathways associated with autism spectrum disorder in neural progenitors. Proc Natl Acad Sci U S A. 2014;111(42):E4468-77.

29. Wilkinson B, Grepo N, Thompson BL, Kim J, Wang K, Evgrafov OV, Lu W, Knowles JA, Campbell DB. The autism-associated gene chromodomain helicase DNA-binding protein 8 (CHD8) regulates noncoding RNAs and autism-related genes. Transl Psychiatry. 2015;5:e568.
30. Wen Y, Alshikho MJ, Herbert MR. Pathway network analyses for autism reveal multisystem involvement, major overlaps with other diseases and convergence upon MAPK and calcium signaling. PLoS One. 2016;11(4): e0153329.

31. Hall J, Trent S, Thomas KL, O'Donovan MC, Owen MJ. Genetic risk for schizophrenia: convergence on synaptic pathways involved in plasticity. Biol Psychiatry. 2015;77(1):52-8.

32. Hall J, Trent S, Thomas KL, O'Donovan MC, Owen M. Genetic risk for schizophrenia: convergence on synaptic pathways involved in plasticity. Biol Psychiatry. 2014.

33. Schizophrenia Working Group of the Psychiatric Genomics Consortium. Biological insights from 108 schizophrenia-associated genetic loci. Nature. 2014:511(7510):421-7.

34. Kwon E, Wang W, Tsai LH. Validation of schizophrenia-associated genes CSMD1, C10orf26, CACNA1C and TCF4 as miR-137 targets. Mol Psychiatry. 2013;18(1):11-2.

35. Pinto D, Delaby E, Merico D, Barbosa M, Merikangas A, Klei L, Thiruvahindrapuram B, Xu X, Ziman R, Wang Z, Vorstman JA, Thompson A, Regan R, Pilorge M, Pellecchia G, Pagnamenta AT, Oliveira B, Marshall CR, Magalhaes TR, Lowe JK, Howe JL, Griswold AJ, Gilbert J, Duketis E, Dombroski BA, De Jonge MV, Cuccaro M, Crawford EL, Correia CT, Conroy J, Conceicao IC, Chiocchetti AG, Casey JP, Cai G, Cabrol C, Bolshakova N, Bacchelli E, Anney R, Gallinger S, Cotterchio M, Casey G, Zwaigenbaum L, Wittemeyer K, Wing K, Wallace S, van Engeland H, Tryfon A, Thomson S, Soorya L, Roge B, Roberts W, Poustka F, Mouga S, Minshew N, McInnes LA, McGrew SG, Lord C, Leboyer M, Le Couteur AS, Kolevzon A, Jimenez Gonzalez P, Jacob S, Holt R, Guter S, Green J, Green A, Gillberg C, Fernandez BA, Duque F, Delorme R, Dawson G, Chaste P, Cafe C, Brennan S, Bourgeron T, Bolton PF, Bolte S, Bernier R, Baird G, Bailey AJ, Anagnostou E, Almeida J, Wijsman EM, Vieland VJ, Vicente AM, Schellenberg GD, Pericak-Vance M, Paterson AD, Parr JR, Oliveira G, Nurnberger JI, Monaco AP, Maestrini E, Klauck SM, Hakonarson H, Haines JL, Geschwind DH, Freitag CM, Folstein SE, Ennis S, Coon H, Battaglia A, Szatmari P, Sutcliffe JS, Hallmayer J, Gill M, Cook EH, Buxbaum JD, Devlin B, Gallagher L, Betancur C, Scherer SW. Convergence of genes and cellular pathways dysregulated in autism spectrum disorders. Am J Hum Genet. 2014;94(5):677-94.

36. Chen ES, Gigek CO, Rosenfeld JA, Diallo AB, Maussion G, Chen GG, Vaillancourt K, Lopez JP, Crapper L, Poujol R, Shaffer LG, Bourque G, Ernst C. Molecular convergence of neurodevelopmental disorders. Am J Hum Genet. 2014:95(5):490-508.

37. Gigek CO, Chen ES, Ota VK, Maussion G, Peng H, Vaillancourt K, Diallo AB, Lopez JP, Crapper L, Vasuta C, Chen GG, Ernst C. A molecular model for neurodevelopmental disorders. Transl Psychiatry. 2015;5:e565.

38. Forrest MP, Waite AJ, Martin-Rendon E, Blake DJ. Knockdown of human TCF4 affects multiple signaling pathways involved in cell survival, epithelial to mesenchymal transition and neuronal differentiation. PLoS One. 2013; 8(8):e73169.

39. Lin M, Zhao D, Hrabovsky A, Pedrosa E, Zheng D, Lachman HM. Heat shock alters the expression of schizophrenia and autism candidate genes in an induced pluripotent stem cell model of the human telencephalon. PLOS One. 2014;9(4):e94968.

40. Mariani J, Simonini MV, Palejev D, Tomasini L, Coppola G, Szekely AM, Horvath TL, Vaccarino FM. Modeling human cortical development in vitro using induced pluripotent stem cells. Proc Natl Acad Sci U S A. 2012; 109(31):12770-5.

41. Lancaster MA, Renner M, Martin CA, Wenzel D, Bicknell LS, Hurles ME, Homfray T, Penninger JM, Jackson AP, Knoblich JA. Cerebral organoids model human brain development and microcephaly. Nature. 2013;501(7467):373-9.

42. Mariani J, Coppola G, Zhang P, Abyzov A, Provini L, Tomasini L, Amenduni M, Szekely A, Palejev D, Wilson M, Gerstein M, Grigorenko EL, Chawarska K, Pelphrey KA, Howe JR, Vaccarino FM. FOXG1-dependent dysregulation of GABA/glutamate neuron differentiation in autism spectrum disorders. Cell. 2015:162(2):375-90.

43. Berghoff EG, Clark MF, Chen S, Cajigas I, Leib DE, Kohtz JD. Evf2 (Dlx6as) IncRNA regulates ultraconserved enhancer methylation and the differential transcriptional control of adjacent genes. Development. 2013;140(21):4407-16.

44. Zhao D, Lin M, Chen J, Pedrosa E, Hrabovsky A, Fourcade HM, Zheng D, Lachman HM. MicroRNA profiling of neurons generated using induced pluripotent stem cells derived from patients with schizophrenia and schizoaffective disorder, and 22q11.2 Del. PLoS One. 2015;10(7):e0132387.

45. Camp JG, Badsha F, Florio M, Kanton S, Gerber T, Wilsch-Brauninger M, Lewitus E, Sykes A, Hevers W, Lancaster M, Knoblich JA, Lachmann R, Paabo S, Huttner WB, 
Treutlein B. Human cerebral organoids recapitulate gene expression programs of fetal neocortex development. Proc Natl Acad Sci U S A. 2015;112(51):15672-7.

46. Bray NL, Pimentel H, Melsted P, Pachter L. Near-optimal probabilistic RNAseq quantification. Nat Biotechnol. 2016;34(5):525-7.

47. Harrow J, Frankish A, Gonzalez JM, Tapanari E, Diekhans M, Kokocinski F, Aken BL, Barrell D, Zadissa A, Searle S, Barnes I, Bignell A, Boychenko V, Hunt T, Kay M, Mukherjee G, Rajan J, Despacio-Reyes G, Saunders G, Steward C, Harte R, Lin M, Howald C, Tanzer A, Derrien T, Chrast J, Walters N, Balasubramanian S, Pei B, Tress M, Rodriguez JM, Ezkurdia I, van Baren J, Brent M, Haussler D, Kellis M, Valencia A, Reymond A, Gerstein M, Guigo R, Hubbard TJ. GENCODE: the reference human genome annotation for The ENCODE Project. Genome Res. 2012;22(9):1760

48. Love Ml, Huber W, Anders S. Moderated estimation of fold change and dispersion for RNA-seq data with DESeq2. Genome Biol. 2014;15(12):550.

49. da Huang W, Sherman BT, Lempicki RA. Systematic and integrative analysis of large gene lists using DAVID bioinformatics resources. Nat Protoc. 2009; 4(1):44-57.

50. da Huang W, Sherman BT, Lempicki RA. Bioinformatics enrichment tools: paths toward the comprehensive functional analysis of large gene lists. Nucleic Acids Res. 2009;37(1):1-13.

51. Chen J, Lin M, Hrabovsky A, Pedrosa E, Dean J, Jain S, Zheng D, Lachman HM. ZNF804A transcriptional networks in differentiating neurons derived from induced pluripotent stem cells of human origin. PLoS One. 2015;10(4):e0124597.

52. Chen J, Lin M, Foxe JJ, Pedrosa E, Hrabovsky A, Carroll R, Zheng D, Lachman HM. Transcriptome comparison of human neurons generated using induced pluripotent stem cells derived from dental pulp and skin fibroblasts. PLoS One. 2013:8(10):e75682.

53. Xu LM, Li JR, Huang Y, Zhao M, Tang X, Wei L. AutismKB: an evidence-based knowledgebase of autism genetics. Nucleic Acids Res. 2012;40(Database issue):D1016-22.

54. Willsey AJ, Sanders SJ, Li M, Dong S, Tebbenkamp AT, Muhle RA, Reilly SK, Lin L, Fertuzinhos S, Miller JA, Murtha MT, Bichsel C, Niu W, Cotney J, ErcanSencicek AG, Gockley J, Gupta AR, Han W, He X, Hoffman EJ, Klei L, Lei J, Liu W, Liu L, Lu C, Xu X, Zhu Y, Mane SM, Lein ES, Wei L, Noonan JP, Roeder K, Devlin B, Sestan N, State MW. Coexpression networks implicate human midfetal deep cortical projection neurons in the pathogenesis of autism. Cell. 2013;155(5):997-1007.

55. Liu L, Lei J, Sanders SJ, Willsey AJ, Kou Y, Cicek AE, Klei L, Lu C, He X, Li M, Muhle RA, Ma'ayan A, Noonan JP, Sestan N, McFadden KA, State MW, Buxbaum JD, Devlin B, Roeder K. DAWN: a framework to identify autism genes and subnetworks using gene expression and genetics. Mol Autism. 2014;5(1):22. -2392-5-22.

56. Iossifov I, O'Roak BJ, Sanders SJ, Ronemus M, Krumm N, Levy D, Stessman HA, Witherspoon KT, Vives L, Patterson KE, Smith JD, Paeper B, Nickerson DA, Dea J, Dong S, Gonzalez LE, Mandell JD, Mane SM, Murtha MT, Sullivan CA, Walker MF, Waqar Z, Wei L, Willsey AJ, Yamrom B, Lee YH, Grabowska E, Dalkic E, Wang Z, Marks S, Andrews P, Leotta A, Kendall J, Hakker I, Rosenbaum J, Ma B, Rodgers L, Troge J, Narzisi G, Yoon S, Schatz MC, Ye K, McCombie WR, Shendure J, Eichler EE, State MW, Wigler M. The contribution of de novo coding mutations to autism spectrum disorder. Nature. 2014;515(7526):216-21.

57. De Rubeis $\mathrm{S}, \mathrm{He}$ X, Goldberg AP, Poultney CS, Samocha K, Cicek AE, Kou Y, Liu L, Fromer M, Walker S, Singh T, Klei L, Kosmicki J, Shih-Chen F, Aleksic B, Biscaldi M, Bolton PF, Brownfeld JM, Cai J, Campbell NG, Carracedo A, Chahrour MH, Chiocchetti AG, Coon H, Crawford EL, Curran SR, Dawson G, Duketis E, Fernandez BA, Gallagher L, Geller E, Guter SJ, Hill RS, Ionita-Laza J, Jimenz Gonzalez P, Kilpinen H, Klauck SM, Kolevzon A, Lee I, Lei I, Lei J, Lehtimaki T, Lin CF, Ma'ayan A, Marshall CR, McInnes AL, Neale B, Owen MJ, Ozaki N, Parellada M, Parr JR, Purcell S, Puura K, Rajagopalan D, Rehnstrom K, Reichenberg A, Sabo A, Sachse M, Sanders SJ, Schafer C, Schulte-Ruther M, Skuse D, Stevens C, Szatmari P, Tammimies K, Valladares O, Voran A, LiSan W, Weiss LA, Willsey AJ, Yu TW, Yuen RK, DDD Study, Homozygosity Mapping Collaborative for Autism, UK10K Consortium, Cook EH, Freitag CM, Gill M, Hultman CM, Lehner T, Palotie A, Schellenberg GD, Sklar P, State MW, Sutcliffe JS, Walsh CA, Scherer SW, Zwick ME, Barett JC, Cutler DJ, Roeder K, Devlin B, Daly MJ, Buxbaum JD. Synaptic, transcriptional and chromatin genes disrupted in autism. Nature. 2014;515(7526):209-15.

58. Allen NC, Bagade S, McQueen MB, loannidis JP, Kavvoura FK, Khoury MJ, Tanzi RE, Bertram L. Systematic meta-analyses and field synopsis of genetic association studies in schizophrenia: the SzGene database. Nat Genet. 2008; 40(7):827-34.
59. Mertens J, Wang QW, Kim Y, Yu DX, Pham S, Yang B, Zheng Y, Diffenderfer KE, Zhang J, Soltani S, Eames T, Schafer ST, Boyer L, Marchetto MC, Nurnberger JI, Calabrese JR, Odegaard KJ, McCarthy MJ, Zandi PP, Alba M, Nievergelt CM, Pharmacogenomics of Bipolar Disorder Study, Mi S, Brennand KJ, Kelsoe JR, Gage FH, Yao J. Differential responses to lithium in hyperexcitable neurons from patients with bipolar disorder. Nature. 2015; 527(7576):95-9.

60. Maier T, Guell M, Serrano L. Correlation of mRNA and protein in complex biological samples. FEBS Lett. 2009;583(24):3966-73.

61. Bayatti N, Sarma S, Shaw C, Eyre JA, Vouyiouklis DA, Lindsay S, Clowry GJ. Progressive loss of PAX6, TBR2, NEUROD and TBR1 mRNA gradients correlates with translocation of EMX2 to the cortical plate during human cortical development. Eur J Neurosci. 2008;28(8):1449-56.

62. Stefansson H, Ophoff RA, Steinberg S, Andreassen OA, Cichon S, Rujescu D, Werge T, Pietilainen OP, Mors O, Mortensen PB, Sigurdsson E, Gustafsson O, Nyegaard M, Tuulio-Henriksson A, Ingason A, Hansen T, Suvisaari J, Lonnqvist J, Paunio T, Borglum AD, Hartmann A, Fink-Jensen A, Nordentoft M, Hougaard D, Norgaard-Pedersen B, Bottcher Y, Olesen J, Breuer R, Moller HJ, Giegling I, Rasmussen HB, Timm S, Mattheisen M, Bitter I, Rethelyi JM, Magnusdottir BB, Sigmundsson T, Olason P, Masson G, Gulcher JR, Haraldsson M, Fossdal R, Thorgeirsson TE, Thorsteinsdottir U, Ruggeri M, Tosato S, Franke B, Strengman E, Kiemeney LA, Group, Melle I, Djurovic S, Abramova L, Kaleda V, Sanjuan J, de Frutos R, Bramon E, Vassos E, Fraser G, Ettinger U, Picchioni M, Walker N, Toulopoulou T, Need AC, Ge D, Lim Yoon J, Shianna KV, Freimer NB, Cantor RM, Murray R, Kong A, Golimbet V, Carracedo A, Arango C, Costas J, Jonsson EG, Terenius L, Agartz I, Petursson $H$, Nothen MM, Rietschel M, Matthews PM, Muglia P, Peltonen L, St Clair D, Goldstein DB, Stefansson K, Collier DA, Genetic Risk and Outcome in Psychosis (GROUP), Kahn RS, Linszen DH, van Os J, Wiersma D, Bruggeman R, Cahn W, de Haan L, Krabbendam L, Myin-Germeys I. Common variants conferring risk of schizophrenia. Nature. 2009;460(7256):744-7.

63. O'Dushlaine C, Kenny E, Heron E, Donohoe G, Gill M, Morris D. The International Schizophrenia Consortium, Corvin A: Molecular pathways involved in neuronal cell adhesion and membrane scaffolding contribute to schizophrenia and bipolar disorder susceptibility. Mol Psychiatry. 2010.

64. Scott-Van Zeeland AA, Abrahams BS, Alvarez-Retuerto Al, Sonnenblick LI, Rudie JD, Ghahremani D, Mumford JA, Poldrack RA, Dapretto M, Geschwind $\mathrm{DH}$, Bookheimer SY. Altered functional connectivity in frontal lobe circuits is associated with variation in the autism risk gene CNTNAP2. Sci Transl Med. 2010;2(56):56ra80.

65. Alarcon M, Abrahams BS, Stone JL, Duvall JA, Perederiy JV, Bomar JM, Sebat J, Wigler M, Martin CL, Ledbetter DH, Nelson SF, Cantor RM, Geschwind DH. Linkage, association, and gene-expression analyses identify CNTNAP2 as an autism-susceptibility gene. Am J Hum Genet. 2008;82(1):150-9.

66. Arking DE, Cutler DJ, Brune CW, Teslovich TM, West K, Ikeda M, Rea A, Guy $\mathrm{M}, \mathrm{Lin} \mathrm{S}, \mathrm{Cook} E \mathrm{E}$, Chakravarti A. A common genetic variant in the neurexin superfamily member CNTNAP2 increases familial risk of autism. Am J Hum Genet. 2008;82(1):160-4.

67. Friedman JI, Vrijenhoek T, Markx S, Janssen IM, van der Vliet WA, Faas BH, Knoers NV, Cahn W, Kahn RS, Edelmann L, Davis KL, Silverman JM, Brunner HG, van Kessel AG, Wijmenga C, Ophoff RA, Veltman JA. CNTNAP2 gene dosage variation is associated with schizophrenia and epilepsy. Mol Psychiatry. 2008;13(3):261-6.

68. Stein JL, Medland SE, Vasquez AA, Hibar DP, Senstad RE, Winkler AM, Toro R Appel K, Bartecek R, Bergmann O, Bernard M, Brown AA, Cannon DM, Chakravarty MM, Christoforou A, Domin M, Grimm O, Hollinshead M, Holmes AJ, Homuth G, Hottenga JJ, Langan C, Lopez LM, Hansell NK, Hwang KS, Kim S, Laje G, Lee PH, Liu X, Loth E, Lourdusamy A, Mattingsdal M, Mohnke S, Maniega SM, Nho K, Nugent AC, O'Brien C, Papmeyer M, Putz B, Ramasamy A, Rasmussen J, Rijpkema M, Risacher SL, Roddey JC, Rose EJ, Ryten M, Shen L, Sprooten E, Strengman E, Teumer A, Trabzuni D, Turner J, van Eijk K, van Erp TG, van Tol MJ, Wittfeld K, Wolf C, Woudstra S, Aleman A, Alhusaini S, Almasy L, Binder EB, Brohawn DG, Cantor RM, Carless MA, Corvin A, Czisch M, Curran JE, Davies G, de Almeida MA, Delanty N, Depondt C, Duggirala R, Dyer TD, Erk S, Fagerness J, Fox PT, Freimer NB, Gill M, Goring HH, Hagler DJ, Hoehn D, Holsboer F, Hoogman M, Hosten N, Jahanshad N, Johnson MP, Kasperaviciute D, Kent Jr JW, Kochunov P, Lancaster JL, Lawrie SM, Liewald DC, Mandl R, Matarin M, Mattheisen M, Meisenzahl E, Melle I, Moses EK, Muhleisen TW, Nauck M, Nothen MM, Olvera RL, Pandolfo M, Pike GB, Puls R, Reinvang I, Renteria ME, Rietschel M, Roffman JL, Royle NA, Rujescu D, Savitz J, Schnack HG, Schnell K, Seiferth N, Smith C, Steen VM, Valdes Hernandez MC, Van den 
Heuvel M, van der Wee NJ, Van Haren NE, Veltman JA, Volzke H, Walker R, Westlye LT, Whelan CD, Agartz I, Boomsma DI, Cavalleri GL, Dale AM, Djurovic S, Drevets WC, Hagoort P, Hall J, Heinz A, Jack Jr CR, Foroud TM, Le Hellard S, Macciardi F, Montgomery GW, Poline JB, Porteous DJ, Sisodiya SM, Starr JM, Sussmann J, Toga AW, Veltman DJ, Walter H, Weiner MW, Alzheimer's Disease Neuroimaging Initiative, EPIGEN Consortium, IMAGEN Consortium, Saguenay Youth Study Group, Bis JC, Ikram MA, Smith AV, Gudnason V, Tzourio C, Vernooij MW, Launer LJ, DeCarli C, Seshadri S, Cohorts for Heart and Aging Research in Genomic Epidemiology Consortium, Andreassen OA, Apostolova LG, Bastin ME, Blangero J, Brunner HG, Buckner RL, Cichon S, Coppola G, de Zubicaray GI, Deary IJ, Donohoe G, de Geus EJ, Espeseth T, Fernandez G, Glahn DC, Grabe HJ, Hardy J, Hulshoff Pol HE, Jenkinson M, Kahn RS, McDonald C, McIntosh AM, McMahon FJ, McMahon KL, Meyer-Lindenberg A, Morris DW, Muller-Myhsok B, Nichols TE, Ophoff RA, Paus T, Pausova Z, Penninx BW, Potkin SG, Samann PG, Saykin AJ, Schumann G, Smoller JW, Wardlaw JM, Weale ME, Martin NG, Franke B, Wright MJ, Thompson PM. Enhancing Neuro Imaging Genetics through Meta-Analysis Consortium: Identification of common variants associated with human hippocampal and intracranial volumes. Nat Genet. 2012:44(5):552-61.

69. Pujadas L, Gruart A, Bosch C, Delgado L, Teixeira CM, Rossi D, de Lecea L, Martinez A, Delgado-Garcia JM, Soriano E. Reelin regulates postnatal neurogenesis and enhances spine hypertrophy and long-term potentiation. J Neurosci. 2010;30(13):4636-49.

70. Niu S, Yabut O, D'Arcangelo G. The Reelin signaling pathway promotes dendritic spine development in hippocampal neurons. J Neurosci. 2008; 28(41):10339-48.

71. Levy AD, Omar MH, Koleske AJ. Extracellular matrix control of dendritic spine and synapse structure and plasticity in adulthood. Front Neuroanat. 2014;8:116

72. Ilfrati J, Orejarena MJ, Lassalle O, Bouamrane L, Gonzalez-Campo C, Chavis P. Reelin, an extracellular matrix protein linked to early onset psychiatric diseases, drives postnatal development of the prefrontal cortex via GluN2BNMDARs and the mTOR pathway. Mol Psychiatry. 2014;19(4):417-26.

73. Habl G, Schmitt A, Zink M, von Wilmsdorff M, Yeganeh-Doost P, Jatzko A, Schneider-Axmann T, Bauer M, Falkai P. Decreased reelin expression in the left prefrontal cortex (BA9) in chronic schizophrenia patients. Neuropsychobiology. 2012;66(1):57-62.

74. Folsom TD, Fatemi SH. The involvement of Reelin in neurodevelopmental disorders. Neuropharmacology. 2013;68:122-35.

75. Fatemi SH, Snow AV, Stary JM, Araghi-Niknam M, Reutiman TJ, Lee S, Brooks Al, Pearce DA. Reelin signaling is impaired in autism. Biol Psychiatry. 2005; 57(7):777-87.

76. Lammert DB, Howell BW. RELN mutations in autism spectrum disorder. Front Cell Neurosci. 2016;10:84.

77. Wang Z, Hong Y, Zou L, Zhong R, Zhu B, Shen N, Chen W, Lou J, Ke J, Zhang T, Wang W, Miao $X$. Reelin gene variants and risk of autism spectrum disorders: an integrated meta-analysis. Am J Med Genet B Neuropsychiatr Genet. 2014; 165B(2):192-200

78. Ribarska T, Goering W, Droop J, Bastian KM, Ingenwerth M, Schulz WA. Deregulation of an imprinted gene network in prostate cancer. Epigenetics. 2014;9(5):704-17.

79. Zhou Y, Zhang X, Klibanski A. MEG3 noncoding RNA: a tumor suppressor. J Mol Endocrinol. 2012;48(3):R45-53.

80. Zhang X, Rice K, Wang Y, Chen W, Zhong Y, Nakayama Y, Zhou Y, Klibanski A. Maternally expressed gene 3 (MEG3) noncoding ribonucleic acid: isoform structure, expression, and functions. Endocrinology. 2010;151(3):939-47.

81. Lu KH, Li W, Liu XH, Sun M, Zhang ML, Wu WQ, Xie WP, Hou YY. Long non-coding RNA MEG3 inhibits NSCLC cells proliferation and induces apoptosis by affecting p53 expression. BMC Cancer. 2013;13:461. 2407-13-461.

82. Zhu J, Liu S, Ye F, Shen $Y$, Tie $Y$, Zhu J, Wei $L$, Jin $Y$, Fu H, Wu Y, Zheng $X$. Long noncoding RNA MEG3 interacts with p53 protein and regulates partial p53 target genes in hepatoma cells. PLoS One. 2015;10(10):e0139790.

83. Paina S, Garzotto D, DeMarchis S, Marino M, Moiana A, Conti L, Cattaneo E, Perera M, Corte G, Calautti E, Merlo GR. Wnt5a is a transcriptional target of Dlx homeogenes and promotes differentiation of interneuron progenitors in vitro and in vivo. J Neurosci. 2011;31(7):2675-87.

84. Miyano M, Horike S, Cai S, Oshimura M, Kohwi-Shigematsu T. DLX5 expression is monoallelic and DIx5 is up-regulated in the Mecp2-null frontal cortex. J Cell Mol Med. 2008;12(4):1188-91.

85. Wang B, Long JE, Flandin P, Pla R, Waclaw RR, Campbell K, Rubenstein JL. Loss of Gsx1 and Gsx2 function rescues distinct phenotypes in Dlx1/2 mutants. J Comp Neurol. 2013;521(7):1561-84.
86. Poitras L, Yu M, Lesage-Pelletier C, Macdonald RB, Gagne JP, Hatch G, Kelly I, Hamilton SP, Rubenstein JL, Poirier GG, Ekker M. An SNP in an ultraconserved regulatory element affects $D / \times 5 / D \mid \times 6$ regulation in the forebrain. Development. 2010;137(18):3089-97.

87. Durak O, Gao F, Kaeser-Woo YJ, Rueda R, Martorell AJ, Nott A, Liu CY, Watson LA, Tsai LH. Chd8 mediates cortical neurogenesis via transcriptional regulation of cell cycle and Wnt signaling. Nat Neurosci. 2016;19(11):1477-88.

88. Pedrosa E, Shah A, Tenore C, Capogna M, Villa C, Guo X, Zheng D, Lachman HM. Beta-catenin promoter ChIP-chip reveals potential schizophrenia and bipolar disorder gene network. J Neurogenet. 2010;24(4):182-93.

89. Serretti A, Drago A, De Ronchi D. Lithium pharmacodynamics and pharmacogenetics: focus on inositol mono phosphatase (IMPase), inositol poliphosphatase (IPPase) and glycogen sinthase kinase 3 beta (GSK-3 beta). Curr Med Chem. 2009;16(15):1917-48.

90. Alda M. Lithium in the treatment of bipolar disorder: pharmacology and pharmacogenetics. Mol Psychiatry. 2015;20(6):661-70.

91. Benedetti F, Poletti S, Radaelli D, Locatelli C, Pirovano A, Lorenzi C, Vai B, Bollettini I, Falini A, Smeraldi E, Colombo C. Lithium and GSK-3beta promoter gene variants influence cortical gray matter volumes in bipolar disorder. Psychopharmacology (Berl). 2015;232(7):1325-36.

92. Cole AR. Glycogen synthase kinase 3 substrates in mood disorders and schizophrenia. FEBS J. 2013;280(21):5213-27.

93. Citrome L. Adjunctive lithium and anticonvulsants for the treatment of schizophrenia: what is the evidence? Expert Rev Neurother. 2009;9(1):55-71.

94. Leucht S, Kissling W, McGrath J: Lithium for schizophrenia. Cochrane Database Syst Rev 2007(3):CD003834.

95. Leucht S, Helfer B, Dold M, Kissling W, McGrath JJ. Lithium for schizophrenia. Cochrane Database Syst Rev. 2015;10:CD003834.

96. Canitano R. Mood stabilizers in children and adolescents with autism spectrum disorders. Clin Neuropharmacol. 2015;38(5):177-82.

97. Siegel M, Beresford CA, Bunker M, Verdi M, Vishnevetsky D, Karlsson C, Teer $\mathrm{O}$, Stedman A, Smith KA. Preliminary investigation of lithium for mood disorder symptoms in children and adolescents with autism spectrum disorder. J Child Adolesc Psychopharmacol. 2014;24(7):399-402.

98. Tracy DK, Joyce DW, Sarkar SN, Mateos Fernandez MJ, Shergill SS. Skating on thin ice: pragmatic prescribing for medication refractory schizophrenia. BMC Psychiatry. 2015;15:174. 015-0559-x.

99. Hibar DP, Stein JL, Renteria ME, Arias-Vasquez A, Desrivieres S, Jahanshad N, Toro R, Wittfeld K, Abramovic L, Andersson M, Aribisala BS, Armstrong NJ, Bernard M, Bohlken MM, Boks MP, Bralten J, Brown AA, Chakravarty MM, Chen Q, Ching CR, Cuellar-Partida G, den Braber A, Giddaluru S, Goldman AL, Grimm O, Guadalupe T, Hass J, Woldehawariat G, Holmes AJ, Hoogman M, Janowitz D, Jia T, Kim S, Klein M, Kraemer B, Lee PH, Olde Loohuis LM, Luciano M, Macare C, Mather KA, Mattheisen M, Milaneschi Y, Nho K, Papmeyer M, Ramasamy A, Risacher SL, Roiz-Santianez R, Rose EJ, Salami A, Samann PG, Schmaal L, Schork AJ, Shin J, Strike LT, Teumer A, van Donkelaar MM, van Eijk KR, Walters RK, Westlye LT, Whelan CD, Winkler AM, Zwiers MP, Alhusaini S, Athanasiu L, Ehrlich S, Hakobjan MM, Hartberg CB, Haukvik UK, Heister AJ, Hoehn D, Kasperaviciute D, Liewald DC, Lopez LM, Makkinje RR, Matarin M, Naber MA, McKay DR, Needham M, Nugent AC, Putz B, Royle NA, Shen L, Sprooten E, Trabzuni D, van der Marel SS, van Hulzen K, Walton E, Wolf C, Almasy L, Ames D, Arepalli S, Assareh AA, Bastin ME, Brodaty H, Bulayeva KB, Carless MA, Cichon S, Corvin A, Curran JE, Czisch M, de Zubicaray GI, Dillman A, Duggirala R, Dyer TD, Erk S, Fedko IO, Ferrucci L, Foroud TM, Fox PT, Fukunaga M, Gibbs JR, Goring HH, Green RC, Guelfi S, Hansell NK, Hartman CA, Hegenscheid K, Heinz A, Hernandez DG, Heslenfeld DJ, Hoekstra PJ, Holsboer F, Homuth G, Hottenga JJ, Ikeda M, Jack Jr CR, Jenkinson M, Johnson R, Kanai R, Keil M, Kent Jr JW, Kochunov P, Kwok JB, Lawrie SM, Liu X, Longo DL, McMahon KL, Meisenzah E, Melle I, Mohnke S, Montgomery GW, Mostert JC, Muhleisen TW, Nalls MA, Nichols TE, Nilsson LG, Nothen MM, Ohi K, Olvera RL, Perez-Iglesias R, Pike GB, Potkin SG, Reinvang I, Reppermund S, Rietschel M, Romanczuk-Seiferth N, Rosen GD, Rujescu D, Schnell K, Schofield PR, Smith C, Steen VM, Sussmann JE, Thalamuthu A, Toga AW, Traynor BJ, Troncoso J, Turner JA, Valdes Hernandez MC, van't Ent D, van der Brug M, van der Wee NJ, van Tol MJ, Veltman DJ, Wassink TH, Westman E, Zielke RH, Zonderman AB, Ashbrook DG, Hager R, Lu L, McMahon FJ, Morris DW, Williams RW, Brunner HG, Buckner RL, Buitelaar JK, Cahn W, Calhoun VD, Cavalleri GL, Crespo-Facorro B, Dale AM, Davies GE, Delanty N, Depondt C, Djurovic S, Drevets WC, Espeseth T, Gollub RL, Ho BC, Hoffmann W, Hosten N, Kahn RS, Le Hellard S, Meyer-Lindenberg A, Muller-Myhsok B, Nauck M, Nyberg L, 
Pandolfo M, Penninx BW, Roffman JL, Sisodiya SM, Smoller JW, van Bokhoven $\mathrm{H}$, van Haren NE, Volzke $\mathrm{H}$, Walter $\mathrm{H}$, Weiner MW, Wen W, White T, Agartz I, Andreassen OA, Blangero J, Boomsma DI, Brouwer RM, Cannon DM, Cookson MR, de Geus EJ, Deary IJ, Donohoe G, Fernandez G, Fisher SE, Francks C, Glahn DC, Grabe HJ, Gruber O, Hardy J, Hashimoto R, Hulshoff Pol HE, Jonsson EG, Kloszewska I, Lovestone S, Mattay VS, Mecocci P, McDonald C, Mclntosh AM, Ophoff RA, Paus T, Pausova Z, Ryten M, Sachdev PS, Saykin AJ, Simmons A, Singleton A, Soininen H, Wardlaw JM, Weale ME, Weinberger DR, Adams HH, Launer LJ, Seiler S, Schmidt R, Chauhan G, Satizabal CL, Becker JT, Yanek L, van der Lee SJ, Ebling M, Fischl B, Longstreth Jr WT, Greve D, Schmidt H, Nyquist P, Vinke LN, van Duijn CM, Xue L, Mazoyer B, Bis JC, Gudnason V, Seshadri S, Ikram MA, Alzheimer's Disease Neuroimaging Initiative, CHARGE Consortium, EPIGEN, IMAGEN, SYS, Martin NG, Wright MJ, Schumann G, Franke B, Thompson PM, Medland SE. Common genetic variants influence human subcortical brain structures. Nature. 2015;520(7546):224-9.

100. Taal HR, St Pourcain B, Thiering E, Das S, Mook-Kanamori DO, Warrington NM, Kaakinen M, Kreiner-Moller E, Bradfield JP, Freathy RM, Geller F, Guxens M, Cousminer DL, Kerkhof M, Timpson NJ, Ikram MA, Beilin LJ, Bonnelykke K, Buxton JL, Charoen P, Chawes BL, Eriksson J, Evans DM, Hofman A, Kemp JP, Kim CE, Klopp N, Lahti J, Lye SJ, McMahon G, Mentch FD, Muller-Nurasyid M, O'Reilly PF, Prokopenko I, Rivadeneira F, Steegers EA, Sunyer J, Tiesler C, Yaghootkar H, Cohorts for Heart and Aging Research in Genetic Epidemiology Consortium, Breteler MM, Decarli C, Breteler MM, Debette S, Fornage M, Gudnason V, Launer LJ, van der Lugt A, Mosley Jr TH, Seshadri S, Smith AV, Vernooij MW, Early Genetics \& Lifecourse Epidemiology Consortium, Blakemore Al, Chiavacci RM, Feenstra B, Fernandez-Banet J, Grant SF, Hartikainen AL, van der Heijden AJ, Iniguez C, Lathrop M, McArdle WL, Molgaard A, Newnham JP, Palmer LJ, Palotie A, Pouta A, Ring SM, Sovio U, Standl M, Uitterlinden AG, Wichmann HE, Vissing NH, DeCarli C, van Duijn CM, McCarthy MI, Koppelman GH, Estivill X, Hattersley AT, Melbye M, Bisgaard H, Pennell CE, Widen E, Hakonarson H, Smith GD, Heinrich J, Jarvelin MR, Jaddoe WW. Early Growth Genetics Consortium: Common variants at $12 \mathrm{q} 15$ and 12q24 are associated with infant head circumference. Nat Genet. 2012;44(5):532-8.

101. Ng SY, Bogu GK, Soh BS, Stanton LW. The long noncoding RNA RMST interacts with SOX2 to regulate neurogenesis. Mol Cell. 2013;51(3):349-59.

102. Chung DW, Volk DW, Arion D, Zhang Y, Sampson AR, Lewis DA Dysregulated ErbB4 splicing in schizophrenia: selective effects on parvalbumin expression. Am J Psychiatry. 2016;173(1):60-8.

103. Spadaro PA, Flavell CR, Widagdo J, Ratnu VS, Troup M, Ragan C, Mattick JS, Bredy TW. Long noncoding RNA-directed epigenetic regulation of gene expression is associated with anxiety-like behavior in mice. Biol Psychiatry. 2015;78(12):848-59.

104. Barry G, Briggs JA, Vanichkina DP, Poth EM, Beveridge NJ, Ratnu VS, Nayler SP, Nones K, Hu J, Bredy TW, Nakagawa S, Rigo F, Taft RJ, Cairns MJ, Blackshaw S, Wolvetang EJ, Mattick JS. The long non-coding RNA Gomafu is acutely regulated in response to neuronal activation and involved in schizophrenia-associated alternative splicing. Mol Psychiatry. 2014;19(4):486-94.

105. Lin M, Pedrosa E, Hrabovsky A, Chen J, Puliafito BR, Gilbert SR, Zheng D, Lachman HM. Integrative transcriptome network analysis of iPSC-derived neurons from schizophrenia and schizoaffective disorder patients with 22q11.2 deletion. BMC Syst Biol. 2016;10(1):105.

106. Cajigas I, Leib DE, Cochrane J, Luo H, Swyter KR, Chen S, Clark BS, Thompson J, Yates 3rd JR, Kingston RE, Kohtz JD. Evf2 IncRNA/BRG1/DLX1 interactions reveal RNA-dependent inhibition of chromatin remodeling. Development. 2015;142(15):2641-52.

107. Szafron LM, Balcerak A, Grzybowska EA, Pienkowska-Grela B, Felisiak-Golabek A, Podgorska A, Kulesza M, Nowak N, Pomorski P, Wysocki J, Rubel T, Dansonka-Mieszkowska A, Konopka B, Lukasik M, Kupryjanczyk J. The novel gene CRNDE encodes a nuclear peptide (CRNDEP) which is overexpressed in highly proliferating tissues. PLoS One. 2015;10(5):e0127475.

108. Guo X, Gao L, Liao Q, Xiao H, Ma X, Yang X, Luo H, Zhao G, Bu D, Jiao F, Shao Q, Chen R, Zhao Y. Long non-coding RNAs function annotation: a global prediction method based on bi-colored networks. Nucleic Acids Res. 2013:41(2):e35

109. van de Devondervoort II, Gordebeke PM, Khoshab N, Tiesinga PH, Buitelaar JK, Kozicz T, Aschrafi A, Glennon JC. Long non-coding RNAs in neurodevelopmental disorders. Front Mol Neurosci. 2013;6:53.
110. Amaral PP, Clark MB, Gascoigne DK, Dinger ME, Mattick JS. IncRNAdb: a reference database for long noncoding RNAs. Nucleic Acids Res. 2011; 39(Database issue):D146-51.

111. Cabili MN, Trapnell C, Goff L, Koziol M, Tazon-Vega B, Regev A, Rinn JL. Integrative annotation of human large intergenic noncoding RNAs reveals global properties and specific subclasses. Genes Dev. 2011;25(18):1915-27.

112. Crawley JN, Heyer WD, LaSalle JM. Autism and cancer share risk genes, pathways, and drug targets. Trends Genet. 2016;32(3):139-46.

113. Garg S, Plasschaert E, Descheemaeker MJ, Huson S, Borghgraef M, Vogels A, Evans DG, Legius E, Green J. Autism spectrum disorder profile in neurofibromatosis type I. J Autism Dev Disord. 2015;45(6):1649-57.

114. Plasschaert E, Descheemaeker MJ, Van Eylen L, Noens I, Steyaert J, Legius E. Prevalence of autism spectrum disorder symptoms in children with neurofibromatosis type 1. Am J Med Genet B Neuropsychiatr Genet. 2015; $168 \mathrm{~B}(1): 72-80$

115. Moos WH, Maneta E, Pinkert CA, Irwin MH, Hoffman ME, Faller DV, Steliou K. Epigenetic treatment of neuropsychiatric disorders: autism and schizophrenia. Drug Dev Res. 2016;77(2):53-72.

116. Abildgaard MO, Borre M, Mortensen MM, Ulhoi BP, Torring N, Wild P, Kristensen H, Mansilla F, Ottosen PD, Dyrskjot L, Orntoft TF, Sorensen KD. Downregulation of zinc finger protein 132 in prostate cancer is associated with aberrant promoter hypermethylation and poor prognosis. Int J Cancer. 2012;130(4):885-95

117. Tommerup $\mathrm{N}$, Vissing $\mathrm{H}$. Isolation and fine mapping of 16 novel human zinc finger-encoding cDNAs identify putative candidate genes for developmental and malignant disorders. Genomics. 1995;27(2):259-64.

118. Iseki H, Takeda A, Andoh T, Kuwabara K, Takahashi N, Kurochkin IV, Ishida H, Okazaki Y, Koyama I. ALEX1 suppresses colony formation ability of human colorectal carcinoma cell lines. Cancer Sci. 2012;103(7):1267-71.

119. Teichroeb JH, Kim J, Betts DH. The role of telomeres and telomerase reverse transcriptase isoforms in pluripotency induction and maintenance. RNA Biol. 2016;13(8):707-19.

120. Nicholls C, Li H, Wang JQ, Liu JP. Molecular regulation of telomerase activity in aging. Protein Cell. 2011;2(9):726-38.

121. Wang Y, Wang Y, Li J, Zhang Y, Yin H, Han B. CRNDE, a long-noncoding RNA, promotes glioma cell growth and invasion through mTOR signaling. Cancer Lett. 2015;367(2):122-8.

122. Cicek MS, Koestler DC, Fridley BL, Kalli KR, Armasu SM, Larson MC, Wang C, Winham SJ, Vierkant RA, Rider DN, Block MS, Klotzle B, Konecny G, Winterhoff BJ, Hamidi H, Shridhar V, Fan JB, Visscher DW, Olson JE, Hartmann LC, Bibikova M, Chien J, Cunningham JM, Goode EL. Epigenome-wide ovarian cancer analysis identifies a methylation profile differentiating clear-cell histology with epigenetic silencing of the HERG K+ channel. Hum Mol Genet. 2013;22(15):3038-47.

123. Capasso M, Diskin SJ, Totaro F, Longo L, De Mariano M, Russo R, Cimmino F, Hakonarson H, Tonini GP, Devoto M, Maris JM, lolascon A. Replication of GWAS-identified neuroblastoma risk loci strengthens the role of BARD1 and affirms the cumulative effect of genetic variations on disease susceptibility. Carcinogenesis. 2013;34(3):605-11.

124. Chan AS, Thorner PS, Squire JA, Zielenska M. Identification of a novel gene NCRMS on chromosome 12q21 with differential expression between rhabdomyosarcoma subtypes. Oncogene. 2002;21(19):3029-37.

125. Williams HJ, Craddock N, Russo G, Hamshere ML, Moskvina V, Dwyer S, Smith RL, Green E, Grozeva D, Holmans P, Owen MJ, O'Donovan MC. Most genome-wide significant susceptibility loci for schizophrenia and bipolar disorder reported to date cross-traditional diagnostic boundaries. Hum Mol Genet. 2011;20(2):387-91.

126. Brennand KJ, Simone A, Tran N, Gage FH. Modeling psychiatric disorders at the cellular and network levels. Mol Psychiatry. 2012;17(12):1239-53.

127. Cattane N, Minelli A, Milanesi E, Maj C, Bignotti S, Bortolomasi M, Bocchio Chiavetto L, Gennarelli M. Altered gene expression in schizophrenia: findings from transcriptional signatures in fibroblasts and blood. PLoS One. 2015;10(2):e0116686.

128. Guella I, Sequeira A, Rollins B, Morgan L, Torri F, van Erp TG, Myers RM, Barchas JD, Schatzberg AF, Watson SJ, Akil H, Bunney WE, Potkin SG, Macciardi F, Vawter MP. Analysis of miR-137 expression and rs1625579 in dorsolateral prefrontal cortex. J Psychiatr Res. 2013;47(9):1215-21.

129. Schizophrenia Psychiatric Genome-Wide Association Study (GWAS) Consortium. Genome-wide association study identifies five new schizophrenia loci. Nat Genet. 2011;43(10):969-76.

130. Green MJ, Cairns MJ, Wu J, Dragovic M, Jablensky A, Tooney PA, Scott RJ, Carr VJ. Genome-wide supported variant MIR137 and severe negative 
symptoms predict membership of an impaired cognitive subtype of schizophrenia. Mol Psychiatry. 2013;18(7):774-80.

131. Brzozka MM, Radyushkin K, Wichert SP, Ehrenreich H, Rossner MJ. Cognitive and sensorimotor gating impairments in transgenic mice overexpressing the schizophrenia susceptibility gene Tcf4 in the brain. Biol Psychiatry. 2010;68(1):33-40.

132. Forrest MP, Hill MJ, Quantock AJ, Martin-Rendon E, Blake DJ. The emerging roles of TCF4 in disease and development. Trends Mol Med. 2014;20(6):322-31.

133. Lopes F, Barbosa M, Ameur A, Soares G, de Sa J, Dias Al, Oliveira G, Cabral P, Temudo T, Calado E, Cruz IF, Vieira JP, Oliveira R, Esteves S, Sauer S, Jonasson I, Syvanen AC, Gyllensten U, Pinto D, Maciel P. Identification of novel genetic causes of Rett syndrome-like phenotypes. J Med Genet. 2016;53(3):190-9.

134. Redin C, Gerard B, Lauer J, Herenger Y, Muller J, Quartier A, Masurel-Paulet A, Willems M, Lesca G, El-Chehadeh S, Le Gras S, Vicaire S, Philipps M, Dumas M, Geoffroy V, Feger C, Haumesser N, Alembik $Y$, Barth M, Bonneau D, Colin E, Dollfus H, Doray B, Delrue MA, DrouinGarraud V, Flori E, Fradin M, Francannet C, Goldenberg A, Lumbroso S, Mathieu-Dramard M, Martin-Coignard D, Lacombe D, Morin G, Polge A, Sukno S, Thauvin-Robinet C, Thevenon J, Doco-Fenzy M, Genevieve D, Sarda P, Edery P, Isidor B, Jost B, Olivier-Faivre L, Mandel JL, Piton A. Efficient strategy for the molecular diagnosis of intellectual disability using targeted high-throughput sequencing. J Med Genet. 2014;51(11):724-36.

135. Giurgea I, Missirian C, Cacciagli P, Whalen S, Fredriksen T, Gaillon T, Rankin J, Mathieu-Dramard M, Morin G, Martin-Coignard D, Dubourg C, Chabrol B, Arfi J, Giuliano F, Claude Lambert J, Philip N, Sarda P, Villard L, Goossens M, Moncla A. TCF4 deletions in Pitt-Hopkins syndrome. Hum Mutat. 2008; 29(11):E242-51.

136. Muhleisen TW, Leber M, Schulze TG, Strohmaier J, Degenhardt F, Treutlein J, Mattheisen M, Forstner AJ, Schumacher J, Breuer R, Meier S, Herms S, Hoffmann P, Lacour A, Witt SH, Reif A, Muller-Myhsok B, Lucae S, Maier W, Schwarz M, Vedder H, Kammerer-Ciernioch J, Pfennig A, Bauer M, Hautzinger M, Moebus S, Priebe L, Czerski PM, Hauser J, Lissowska J, Szeszenia-Dabrowska N, Brennan P, McKay JD, Wright A, Mitchell PB, Fullerton JM, Schofield PR, Montgomery GW, Medland SE, Gordon SD, Martin NG, Krasnow V, Chuchalin A, Babadjanova G, Pantelejeva G, Abramova LI, Tiganov AS, Polonikov A, Khusnutdinova E, Alda M, Grof P, Rouleau GA, Turecki G, Laprise C, Rivas F, Mayoral F, Kogevinas M, GrigoroiuSerbanescu M, Propping P, Becker T, Rietschel M, Nothen MM, Cichon S. Genome-wide association study reveals two new risk loci for bipolar disorder. Nat Commun. 2014;5:3339.

137. Potkin SG, Turner JA, Guffanti G, Lakatos A, Fallon JH, Nguyen DD, Mathalon D, Ford J, Lauriello J, Macciardi F. FBIRN: a genome-wide association study of schizophrenia using brain activation as a quantitative phenotype. Schizophr Bull. 2009;35(1):96-108.

138. Vierbuchen T, Ostermeier A, Pang ZP, Kokubu Y, Sudhof TC, Wernig M. Direct conversion of fibroblasts to functional neurons by defined factors. Nature. 2010;463(7284):1035-41.

139. Gao Z, Lee P, Stafford JM, von Schimmelmann M, Schaefer A, Reinberg D. An AUTS2-Polycomb complex activates gene expression in the CNS. Nature. 2014;516(7531):349-54

140. Fan Y, Qiu W, Wang L, Gu X, Yu Y. Exonic deletions of AUTS2 in Chinese patients with developmental delay and intellectual disability. Am J Med Genet A. 2016;170(2):515-22.

141. Liu Y, Zhao D, Dong R, Yang X, Zhang Y, Tammimies K, Uddin M, Scherer SW, Gai Z. De novo exon 1 deletion of AUTS2 gene in a patient with autism spectrum disorder and developmental delay: a case report and a brief literature review. Am J Med Genet A. 2015;167(6):1381-5.

142. Denk D, Nebral K, Bradtke J, Pass G, Moricke A, Attarbaschi A, Strehl S. PAX5AUTS2: a recurrent fusion gene in childhood B-cell precursor acute lymphoblastic leukemia. Leuk Res. 2012;36(8):e178-81.

143. Feng J, Bi C, Clark BS, Mady R, Shah P, Kohtz JD. The Evf-2 noncoding RNA is transcribed from the Dlx-5/6 ultraconserved region and functions as a Dlx-2 transcriptional coactivator. Genes Dev. 2006;20(11):1470-84.

144. Benes FM, Vincent SL, Marie A, Khan Y. Up-regulation of GABAA receptor binding on neurons of the prefrontal cortex in schizophrenic subjects. Neuroscience. 1996;75(4):1021-31.

145. Gonzalez-Burgos G, Cho RY, Lewis DA. Alterations in cortical network oscillations and parvalbumin neurons in schizophrenia. Biol Psychiatry. 2015; 77(12):1031-40.
146. Hashemi E, Ariza J, Rogers H, Noctor SC, Martinez-Cerdeno V. The number of parvalbumin-expressing interneurons is decreased in the medial prefrontal cortex in autism. Cereb Cortex. 2016, [Epub ahead of print].

147. Hochberg Y, Benjamini Y. More powerful procedures for multiple significance testing. Stat Med. 1990;9(7):811-8.

\section{Submit your next manuscript to BioMed Central and we will help you at every step:}

- We accept pre-submission inquiries

- Our selector tool helps you to find the most relevant journal

- We provide round the clock customer support

- Convenient online submission

- Thorough peer review

- Inclusion in PubMed and all major indexing services

- Maximum visibility for your research

Submit your manuscript at www.biomedcentral.com/submit
C Biomed Central 